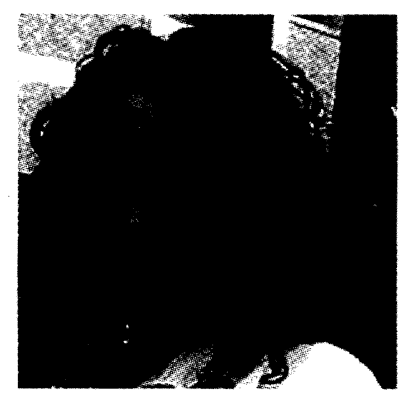

Julie D. Cantor

Julie Cantor holds BA and MA degrees in psychology from Stanford University. After graduating from Stanford, Julie pursued her long-standing interest in medical ethics by serving as research associate at the University of California, San Francisco's Program in Medical Ethics. She continued her education at Yale Law School and the University of California at Berkeley's Boalt Hall School of Law, where she received her JD. Julie graduated from the Yale University School of Medicine in May of 2005. During her time at Yale, she taught two undergraduate seminars that she created as a Lecturer at Yale College entitled, "The Stork in the 21st Century: Reproduction, Medical Ethics, and the Law," and "Medical Ethics, Law, and Literature." Julie has lectured on topics at the intersection of law and medicine at universities around the country, and her writing has appeared in national medical and legal publications. 



\title{
OF PILLS AND NEEDLES: INVOLUNTARILY MEDICATING THE PSYCHOTIC INMATE WHEN EXECUTION LOOMS
}

\author{
Julie D. Cantor, M.D. \\ "The path I tread will lead me \\ Either to madness or to execution ...." \\ - Don Carlos, crown prince of Spain, in Friedrich \\ Schiller's play Don Carlos ${ }^{1}$
}

\section{INTRODUCTION}

On a warm summer evening in $1979,{ }^{2}$ Charles Laverne Singleton walked into York's Grocery, a local convenience store in the tiny Arkansas town of Hamburg, ${ }^{3}$ with a .25 caliber pistol in hand and robbery in mind. ${ }^{4}$ Owner Mary Lou York, a 62-year-old mother of four, was minding the store from behind the check-out counter. ${ }^{5}$ Singleton walked up to her and asked for some cigarettes. ${ }^{6}$ When she moved to grab a pack, Singleton took out his gun, announced that he was robbing her and that he wanted all of the money in the cash register. ${ }^{7}$ But York was no easy mark. As John Frank Gibson, the former Ashley County prosecutor who tried Singleton, recalled, "She was the type of person who would protect her belongings. She was not going to be pushed around by anybody."8

When York fought back, Singleton fired his gun at her. ${ }^{9}$ He missed. ${ }^{10}$ Undeterred, he took out a rusty knife and attacked again, stabbing York twice

1. FRIEDRICH SCHILLER, DON CARLOS AND MARY STUART 280 (Peter Oswald, trans., Oxford Univ. Press 2002) (1787).

2. The mean temperature in North Little Rock, Arkansas was 72.5 degrees F on June 1, 1979, the day of the murder. The Old Farmer's Almanac, Weather: Weather History for One Day, at http://www.almanac.com/weatherhistory/oneday.php? number $=723400$ \&day $=1 \&$ month $=6 \&$ year $=1979$ (last visited Apr. 17, 2005) (on file with the Indiana Health Law Review). Singleton v. Norris, 319 F.3d 1018, 1020 (8th Cir. 2003) (noting that the crime occurred on June 1, 1979 at approximately 7:30 p.m.).

3. Hamburg's population hovers near 3000. United States City Facts, Facts About Hamburg, Arkansas, at http://www.uscityfacts.com/city.htm?state=arkansas\&city=Hamburg (last visited Apr. 17, 2005) (on file with the Indiana Health Law Review).

4. Dateline NBC: Crazy Like a Fox?; An Insane Death Row Inmate Becomes the Center of a Legal Debate When He Refuses to Take His Medication to Avoid Being Executed (NBC television broadcast, Apr. 5, 1999) [hereinafter Dateline NBC: Crazy Like a Fox?].

5. Id.

6. Id.

7. Id.

8. Id.

9. Dateline NBC: Crazy Like a Fox?, supra note 4.

10. Id. 
in the neck ${ }^{11}$ as she screamed, "Charles Singleton is killing me[!]"12 With a small amount of cash in tow, ${ }^{13}$ Singleton left his wounded victim behind. Police officers soon arrived, and an ambulance scooped up the bleeding York. She felt that her death was imminent. As she told one of the officers, "[T] here's no way I can be all right[;] you know I'm not going to make it. I've lost too much blood."14 She was right. She died en route to the hospital.

It was an inelegant crime, and Singleton's culpability was undeniable. Damning eyewitness testimony, his own bloodstained clothing, York's excited utterance during the crime and her dying declaration on the way to the hospital were convincing. ${ }^{15}$ Singleton also led police to the weapons he used that night, and he told them, "I stabbed her. I remember doing it." 16 As the Arkansas Supreme Court remarked, "The evidence of guilt in this case is overwhelming." 17 Prosecutor Gibson concurred. "With regard to the guilt," he remembered, "it was pretty open and shut." 18

A jury convicted Singleton of aggravated robbery and felony murder, and the court sentenced him to life imprisonment and death, respectively, for his crimes. The Arkansas Supreme Court affirmed the capital murder conviction and sentence, ${ }^{19}$ and the State set an execution date for June $4,1982 .{ }^{20}$ Singleton again appealed and was granted a temporary stay of execution. ${ }^{21}$ That decision marked the beginning of an epic journey through the appellate court system, from the state courts of Arkansas ${ }^{22}$ to the Eighth Circuit Court of Appeals ${ }^{23}$ to the United States Supreme Court ${ }^{24}$ and back again. ${ }^{25}$

11. Id.

12. Singleton v. State, 623 S.W.2d 180, 181 (Ark. 1981) (detailing facts of the case).

13. Singleton stole \$69. Dateline NBC: Crazy Like a Fox?, supra note 4.

14. Singleton, 623 S.W.2d at 181.

15. Id.

16. Dateline NBC: Crazy Like a Fox?, supra note 4.

17. Singleton, 623 S.W.2d at 181.

18. Dateline NBC: Crazy Like a Fox?, supra note 4.

19. Singleton v. State, 623 S.W.2d 180 (Ark. 1981) (affirming Singleton's conviction and sentence for capital felony murder, but setting aside the aggravated robbery conviction on double jeopardy grounds).

20. Singleton v. Norris, 319 F.3d 1018, 1021 (8th Cir. 2003).

21. Singleton v. Lockhart, 653 F. Supp. 1114, 1115 (E.D. Ark. 1986), rev'd and remanded, 871 F.2d 1395 (8th Cir. 1989) (noting that on "June 1, 1982, this Court granted petitioner a stay of execution and petitioner's first petition for writ of habeas corpus was filed."). After hearing the case, the district court vacated the death sentence and imposed a penalty of life without parole. $I d$. at 1138 . The Eighth Circuit reversed that decision.

22. See, e.g., Singleton v. State, 623 S.W.2d 180 (Ark. 1981); Singleton v. Endell, 870 S.W.2d 742 (Ark. 1994).

23. See, e.g., Singleton v. Lockhart, 871 F.2d 1395 (8th Cir. 1989) (affirming the district court's denial of a petition for habeas corpus, reversing the portion of the order that vacated Singleton's death sentence, and remanding to reinstate that penalty).

24. Singleton v. Norris, 506 U.S. 964 (1992) (denying the petition for writ of certiorari). 25. Singleton v. Norris, 540 U.S. 832 (2003) (denying the petition for writ of certiorari). 
Singleton's appeals generally involved issues that fell squarely within the purview of criminal law - the trial judge erred when he failed to excuse prospective jurors for cause; ${ }^{26}$ the State violated rules of evidence, ${ }^{27}$ Singleton's lawyer was ineffective. ${ }^{28}$ But by 1998 , the issue had changed to one that involved medicine, ethics, and law. ${ }^{29}$

\section{A. Descent Into Psychosis}

The record is clear that at the time of the crime, Singleton was not suffering from an appreciable mental illness. In 1979, at the insistence of his attorney, Singleton underwent psychological and psychiatric testing at Arkansas State Hospital. ${ }^{30}$ Mental health professionals diagnosed him with severe antisocial personality disorder and habitual excessive drinking, and they pegged his IQ at eighty-three, placing him in "the dull normal range of intellectual functioning." "31 But, they noted, he was not "overtly psychotic or out of contact with reality at this time" and "probably was not at the time of the commission of the alleged offense." "32 Singleton, they found, understood the proceedings against him and could assist his attorney, and he failed to qualify for an insanity defense. ${ }^{33}$ On appeal, he argued that the trial court erred when it allowed him to waive his right to present mitigating evidence at the sentencing phase of his trial, and he lost-the Eighth Circuit Court of Appeals found that his mental state at the time of the waiver was adequate. ${ }^{34}$ As that court explained, "there is no question but that Singleton was not laboring under any mental disability that would call into question his competence to knowingly and intelligently waive his right to present mitigating evidence." 35

26. Singleton v. State, 623 S.W.2d 180, 181 (Ark. 1981).

27. Singleton, 623 S.W.2d at 182.

28. Singleton v. Lockhart, 653 F. Supp. 1114, 1116 (E.D. Ark. 1986).

29. Singleton v. Norris, 964 S.W.2d 366 (Ark. 1998).

30. Singleton v. Lockhart, 962 F.2d 1315, 1318 (8th Cir. 1992) (discussing the psychological and psychiatric testing of Singleton that occurred at the time of the trial).

31. Singleton, 962 F.2d at 1318.

32. Id. Still, when Singleton recounted his state of mind at the time of the crime during a 1999 interview, he failed to sound completely rational. His take on killing York and what he would say to her family:

That's very difficult. But I'm sorry I took a life, but it was not their mother whose life I was involved with. I was in a different reality and the person I was slaying was Mary from the mother of Jesus in the Bible. That's the reality I was in, because I was in a-a religious state of mind, something like, you've ever seen that show, 'Millennium'? . . It was-it was about religion, but it wasn't reality.

Dateline NBC: Crazy Like a Fox?, supra note 4. Of course, Singleton's state of mind at the time of that interview may have colored his recollection of the past.

33. Singleton, 962 F.2d at $1317-21$ (recounting the trial specifics).

34. Id. at 1318.

35. Id. at 1322 . 
During his incarceration, though, Singleton's behavior changed. Early on, physicians treated him with medication for anxiety and depression. ${ }^{36}$ By 1987 , his mental clarity deteriorated and symptoms of severe mental illness emerged. He believed that demons possessed his cell and that "demon blood" stained its walls. He lost weight. He experienced hallucinations ("that his brother would come to his locked prison cell and take him out of it for walks") and delusions ("that a prison doctor had planted some type of device in his right ear and that his thoughts were being stolen from him when he read the Bible"). Arkansas correctional facility physicians diagnosed him with paranoid schizophrenia ${ }^{37}$ and administered antipsychotic medication to control his symptoms. ${ }^{38}$ At first, Singleton took those medications voluntarily. ${ }^{39}$ But from time to time, he refused to take them. ${ }^{40}$ During those unmedicated

36. Singleton v. Norris, 319 F.3d 1018, 1030 (8th Cir. 2003) (Heaney, J., dissenting). The facts recounted in this paragraph that relate to Singleton's psychotic behavior are compiled from this dissenting opinion.

37. The Diagnostic and Statistical Manual of Mental Disorders is the definitive text that lists diagnostic criteria for mental disorders. For a diagnosis of schizophrenia, the patient must first exhibit " $[t]$ wo (or more) of the following, each present for a significant portion of time during a 1-month period (or less if successfully treated):

(1) delusions

(2) hallucinations

(3) disorganized speech (e.g., frequent derailment or incoherence)

(4) grossly disorganized or catatonic behavior

(5) negative symptoms, i.e., affective flattening, alogia, or avolition."

AM. PSYCHIATRIC AsS'N, DiAGNOSTIC AND STATISTICALMANUAL OFMENTAL DISORDERS: TEXT REVISION 298-312 (4th ed. 2000). Second, the patient needs to demonstrate social or occupational dysfunction, such as difficulty with work, interpersonal relations, or self-care. These difficulties must persist for at least 6 months. Further, the disorder must not be due to a schizoaffective or mood disorder, and it may not stem from medications, street drugs, or other exogenous sources. Id. at 298-312. Paranoid schizophrenia is a subtype of the disorder, and the criteria for establishing the diagnosis are: (1) "Preoccupation with one or more delusions or frequent auditory hallucinations" and (2) "None of the following is prominent: disorganized speech, disorganized or catatonic behavior, or flat or inappropriate affect." Id. at 313-14.

38. Singleton, 319 F.3d at 1030 (Heaney, J., dissenting). Although antipsychotic medications and their considerable side effects have been at the core of other cases like Riggins $v$. Nevada, 504 U.S. 127 (1992), and Sell v. United States, 539 U.S. 166 (2003), the issues in Singleton never turned on the medications themselves. Consequently, the record fails to identify the exact medications Singleton took. In general, though, current medications used to treat schizophrenia include the so-called "typical" antipsychotics, which include chlorpromazine, thioridazine, and haloperidol. These medications tend to decrease positive symptoms of the illness, like delusions and hallucinations, but they have a limited effect on negative symptoms, like apathy and loss of affect. The "atypical" antipsychotics, like risperidone, olanzapine, clozapine, may also be part of a medication regimen. Their side effects may be severe. For example, clozapine can cause agranulocytosis (a deficiency of white blood cells), which has a death rate of 1 per 10,000 patients. Other blood disorders may occur. The side effect profile also includes sedation, weight gain, blood pressure regulation difficulties, and incontinence. For more information about diagnosing and treating schizophrenia, see generally Herbert $Y$. Meltzer \& S. Hossein Fatemi, Schizophrenia, in CURRENT DiaGnosis \& TREATMENT IN PSYCHIATRY 260, 260-277 (Michael H. Ebert et al. eds, 2000).

39. Singleton, 319 F.3d at 1030 (Heaney, J., dissenting) (recounting events that elucidate the extent of Singleton's illness).

40. Id. 
periods, Singleton invariably lapsed into a psychosis. According to court records, "Whenever he was off his medication, his symptoms would resurface, and he would again experience hallucinations . . . [H] was observed stripping off his clothes and speaking in a strange language. He became paranoid and delusional, and believed that he had already been executed."41

Over the years, his psychosis became more than disturbing - it became dangerous. By 1995, prison psychiatrists heightened their level of concern and said that Singleton was a paranoid schizophrenic with a "high "potential for violence." 42 At one point, he told a social worker that he was "on a mission from God to kill him and the president."43 In 1997, his psychiatrists discontinued his medications to assess his status without them. He quickly became "very hostile, belligerent, and probably psychotic." 44 He announced that he was "on a mission from God" and that he needed to kill his treating physician and the President. ${ }^{45}$ This threat, coupled with another to kill his psychiatrist, led observers to note that his demeanor displayed "lethal hostility." ${ }^{\prime 46}$ During a three-week period without medications, he continued to display psychotic behavior: telling staff that he had been "freed by the Eighth Circuit and the U.S. Supreme Court," exhibiting poor hygiene, informing the staff that he was "God and the Supreme Court" and that his sentence had been vacated. ${ }^{47} \mathrm{He}$ was also observed to be "nude and 'zombie-like"" in his cell, to be "almost nonresponsive," to have torn up and flushed his mattress, and to have flooded his cell. ${ }^{48}$ As Singleton's attorney explained, "When he is off his medication, he eventually loses a lot of weight, stops eating, completely loses all control of his hygiene, and essentially goes into wild gesticulations and ... [talks about] whatever word salad pops into his head." ${ }^{\text {49 }}$ A clear pattern emerged-Singleton was floridly psychotic without psychiatric medications. Prison psychiatrists then created a plan to medicate Singleton, with or without his consent, if he became psychotic, dangerous, and refused to participate in his treatment. ${ }^{50}$

41. Id at 1031.

42. Dateline NBC: Crazy Like a Fox?, supra note 4 (quoting Arkansas Department of Corrections psychiatrists' records).

43. Id.

44. Singleton v. Norris, 319 F.3d 1018, 1031 (8th Cir. 2003).

45. Id.

46. Dateline NBC: Crazy Like a Fox?, supra note 4.

47. Singleton, 319 F.3d at 1031.

48. Id.

49. American Morning: Two Death Row Inmates Scheduled to Die Tonight in Arkansas (CNN television broadcast, Jan. 7, 2004).

50. Periodically, psychiatrists on the Arkansas penitentiary's Medication Review Panel adjusted Singleton's medication regimen to keep his symptoms in check. At times, even while medicated, he displayed psychotic symptoms. At one point, he described himself as the victim of a voodoo curse. At another, he suffered from "disturbing hallucinations in which his food turned to worms and cigarettes became bones." Singleton, 319 F.3d at 1031. 
By his own admission, Singleton preferred his medicated, non-psychotic state. $^{51}$ He explained the role of his antipsychotic drugs in a 1999 interview with NBC's Dateline: "They get me-they put me back in touch with-I'm able to listen to you and understand what you're talking about without hearing another story." 52 Although the medications reduced his symptoms and calmed his hallucinations, they also created a dilemma. They made him sane enough, as the current law defines, for execution. ${ }^{53}$ Even his longtime attorney Jeffrey Rosenzweig $^{54}$ agreed that under the relevant legal standard, Singleton was lucid enough to die when medicated. ${ }^{55}$ But without antipsychotic drugs, he did not meet the essential criteria and, legally, could not face capital punishment.

The coalescence of involuntarily administered antipsychotic medications and competency for execution created a novel and controversial issue that became the basis of Singleton's final appeal. ${ }^{56}$ The Arkansas Supreme Court stated the question succinctly: May the State "mandatorily medicate [Singleton] with antipsychotic drugs in order to keep him from being a danger to himself and others when a collateral effect of that medication is to render him competent to understand the nature and reason for his execution[?]"57 Or, as Singleton put it, "Am I too sane to live, or too insane to die?"58 The cynical view of that question is that Singleton was clever and manipulative. Like most people, he would do just about anything to forestall his death. The more charitable view is that Singleton found an Achilles heel in the execution process and physicians' involvement with it, one that created what some physicians consider to be an intolerable dilemma.

51. Id. at 1025. ("The record before us indicates that Singleton prefers to take the medication rather than be in an unmedicated and psychotic state.").

52. Dateline NBC: Crazy Like a Fox?, supra note 4.

53. See discussion on Washington v. Harper, 494 U.S. 210 (1990), infra Part I.A.

54. Paul Greenberg, Time is Running Out and So is Sanity in the Curious Case of Charles Singleton, ARK. DEMOCRAT-GAZETTE, Jan. 4, 2004, at 72 (noting that Rosenzweig had represented Singleton since 1981).

55. Kevin Drew, Arkansas Prepares to Execute Mentally Ill Inmate, CNN.COM, Jan. 5, 2004, at http://www.cnn.com/2004/LAW/01/05/singleton.death.row/index.html (last visited Apr. 17, 2005) (on file with the Indiana Health Law Review).

56. This and related issues involving involuntary medication and prisoners have inspired heated debate. See, e.g., Bruce A. Arrigo \& Jeffrey J. Tasca, Right to Refuse Treatment, Competency to be Executed, and Therapeutic Jurisprudence: Toward A Systemic Analysis, 23 L. \& PSYCHOL. REV. 1, 1-47 (1999); Fred Cohen \& Joel Dvoskin, Inmates with Mental Disorders: A Guide to Law and Practice, 16 MENTAL\& PHYSICALDISABILITY L. Rep. 339, 33946 (1992); Kirk Heilbrun et al., The Debate on Treating Individuals Incompetent for Execution, 149 AM. J. PSYCHIATRY 596, 596-97 (1992); R. Andrew Shultz-Ross, Theoretical Difficulties in the Treatment of Mentally Ill Prisoners, 38 J. FoRENSIC SCI. 426, 428 (1993); Bruce J. Winick, Competency to be Executed: A Therapeutic Jurisprudence Perspective, 10 BEHAV. SCI. \& L. 317, 317-37 (1992).

57. Singleton v. Norris, 964 S.W.2d 366, 368 (Ark. 1998).

58. Dateline NBC: Crazy Like a Fox?, supra note 4. 


\section{B. Article Overview}

This Article argues that the Eighth Circuit's holding in Singleton v. Norris was correct and that it is ethical and perhaps even required for physicians to medicate psychotic death row inmates. Through an analysis that uses legal, ethical, and policy arguments, this paper analyzes the salient dilemma and discerns the proper role for the physician who cares for a patient like Singleton. This approach aims to illuminate the doctor's dilemma, and it speaks to whether a physician who medicates an inmate like Singleton violates an ethical duty to the patient or the profession. Part I offers historical and contextual background about the rights that individuals with mental illnesses have secured in both the civil and criminal settings. Part II discusses the Eighth Circuit's opinion in Singleton v. Norris and analyzes the arguments against and for forcibly medicating Singleton. Part III offers principled solutions for physicians who, despite the Article's analysis, believe that it was indefensible to medicate Singleton. Finally, Part IV is an epilogue, offering concluding thoughts on the case.

\section{MENTAL ILLNESS AND THE LEGAL SYSTEM}

Discussions about the rights of the mentally ill and advocacy to guarantee those rights by law are relatively new. ${ }^{59}$ Historically, the insane were relegated to society's periphery - ostracized, feared, ignored. ${ }^{60}$ After World War II, author and journalist Albert Deutsch investigated the conditions of state-run institutions for the mentally ill, and his book on this subject begins with a discussion of the sad legacy of mental illness. "Insanity was once considered a sin or the consequence of sin," he writes. ${ }^{61}$ "The insane were punished as sinners or imprisoned as criminals ... sent to priests to be exorcised of the devils within them ... hanged or burned as witches, particularly during the terrible witchcraft mania that swept through Europe and parts of America in the seventeenth century." ${ }^{2}$ Witch-hunts abated as religious fervor gave way to Enlightenment ideals of free thought, and theories about

59. Paul S. APPElbaum, Almost aReVolution: MentalHealth LaW and THE Limits OF CHANGE 3-16 (1994).

60. See AlBert Deutsch, The Shame OF THE STATES (Gerald N. Grob et al. eds., Arno Press 1973) (1948); EDWARD SHORTER, A HISTORY OF PSYCHIATRY: FROM THE ERA OF THE ASYLUM TO THE AGE OF PROZAC (1997); INSANITY, INSTITUTIONS AND SOCIETY 1800-1914 (Joseph Melling \& Bill Forsythe, eds., 1999). For a discussion of the history of mental illness and the rise of psychiatry, see ROY PORTER, MADNESS (2002).

61. DEUTSCH, supra note 60, at 9. Deutsch visited "scores and perhaps hundreds" of psychiatric institutions. $I d$. at 19 . He photographed and chronicled the wretched conditions at prominent institutions like the Philadelphia State Hospital for Mental Disease (Byberry) and Ohio's Cleveland State Hospital.

62. Id. at 9. Porter notes that "over 200,000 people, mainly women, were executed during the witch craze" in 16th century Europe. PORTER, supra note 60, at 25. 
demons were replaced with ones about psychopathology. ${ }^{63}$ As University of York historian Anne Digby writes about this era in England, "Although there was a range of attitudes towards madness, the dominant conception within this spectrum was beginning to change . . Madness was seen less as a spiritual disease, in which the mad, possessed by the devil, were sinful or immoral, and more as a secular condition." S4 Social scapegoats shifted from witches to "beggars, criminals, and vagrants." 65 By the early nineteenth century, " $[t]$ he great majority of the insane were then housed in local poorhouses and jails and treated as common paupers and criminals." Still, problems abound as the mentally ill were mistreated and tortured, "chained to walls and floors of filthy cells; beaten and whipped; subjected to solitary confinement for years; manacled, camisoled, and cribbed without provocation; driven into hopeless insanity when they might have been cured by prompt and effective treatment or even by simple humane care." ${ }^{97}$ Later, democratic principles inspired a new sense of sympathy among the public for "their defenseless brethren." In 1841 in the United States, Dorothea Lynde Dix, a lifelong advocate for the mentally ill, began her crusade to move the insane to state hospitals. ${ }^{69}$ Population growth and the Industrial Revolution contributed to changes in social conditions, which led to creating public institutions to house the mentally ill. $^{70}$

Although a new sense of social responsibility marked an important step towards humane treatment for individuals with mental illness, state-run institutions quickly filled, became overcrowded, and remained problematic well into the twentieth century. As Montagu Lomax, a physician who treated patients at various European asylums during the early 1900 s, noted, "I have no hesitation in saying that ... our present system of asylum administration is a failure."71 Around the time of America's baby boom, Deutsch found that "not a single state mental hospital in the whole country [met] all the minimum standards of care and treatment established twenty years ago by the American Psychiatric Association." "72 The landscape was bleak, at best.

63. PORTER, supra note 60 , at 31-32.

64. ANNE DIGBY, MADNESS, MORALITY AND MEDICINE 1 (1985).

65. PORTER, supra note 60 , at 32 .

66. DEUTSCH, supra note 60, at 33-34.

67. Id. But see PORTER, supra note 60 , at $99-100$ (discussing the varying quality of asylums and that some "could also be supportive").

68. DEUTSCH, supra note 60, at 33-34.

69. Id. at 35 .

70. Id. at 33-34.

71. MONTAGULOMAX, THE EXPERIENCES OF ANASYLUMDOCTOR 14(1921). Lomax was remarkably prophetic about the nature of mental illness and its basis in neurochemical pathology. He wrote, "We cannot explore the brain-cells of a madman during an attack of acute mania or melancholia, and say whether they are or are not materially affected. The probability-nay, the certainty-is that they are[.]" Id. at 35.

72. DEUTSCH, supra note 60, at 183. 


\section{A. Civil Rights Guarantees}

By the 1960 s, change was afoot in mental health law, as it was in so many areas of society. ${ }^{73}$ It was time for action. Incremental changes in and moderate attention to mental health care were not enough. Sadly, "the principles on which mental health law was based in 1961 were the same ones that prevailed in 1881."74 While advances in pharmacological treatment were critical in improving care on the medical front, ${ }^{75}$ legal changes were valuable as well. In the 1964 Hospitalization of the Mentally Ill Act, Congress codified the right of the confined mentally ill patient to treatment, not just custodial care. ${ }^{76}$ The Act guaranteed that "[a] person hospitalized in a public hospital for a mental illness shall, during his hospitalization, be entitled to medical and psychiatric care and treatment."77 The extensive hearings held while Congress crafted this legislation illustrate heightened attention to the plight of people with mental illnesses. ${ }^{78}$ Today, it is hardly debatable that the hospitalized mentally ill patient has a statutory right to and requires psychiatric treatment.

The right to refuse treatment is a necessary corollary of that right to treatment. ${ }^{79}$ Informed consent, which encompasses the right to choose, accept, or refuse medical treatment, is a core tenet of medical ethics. ${ }^{80}$ The idea gained legal grounding in Justice Louis Brandeis's Olmstead opinion, which discussed the importance of the right "to be let alone"81 and in Justice Benjamin Cardozo's opinion for the Court of Appeals of New York in Schloendorff, which established the principle that "[e]very human being of adult years and sound mind has a right to determine what shall be done with his own body . . . "82 More recently, the Supreme Court has recognized the

73. APPELBAUM, supra note 59, at 4 (discussing the "thoroughgoing overhaul of law applicable to the mentally ill" that took place from the late 1960 s to the mid-1980s).

74. $I d$. at 3 (citing THE MENTALly DisABLED AND THE LAW (F.T. Lindman \& D.M. McIntyre, eds., 1961)).

75. See, e.g., W. Wolfgang Fleischhacker, Pharmacological Treatment of Schizophrenia: A Review, in SCHIZOPHRENIA 75, 75-76 (Mario Maj \& Norman Sartorius eds., 1999)(explaining that antipsychotic treatment introduced in the 1950 s was a "breakthrough" for the treatment of schizophrenia).

76. 1964 Hospitalization of the Mentally Ill Act, $\S 21-562,79$ Stat. 750, 758 (1965) (codified as amended at D.C. CODE ANN. $§ 21-562(2005)$ ).

77. Id.

78. To Protect the Constitutional Rights of the Mentally Ill: Hearing on S. 935 Before the Subcomm. on Constitutional Rights of the S. Com. on the Judiciary 88th Cong. 12 (1963).

79. For more on the contours of the right to refuse treatment see generally BRUCE J. WINICK, THE RIGHT TO REFUSE MENTAL HEALTH TREATMENT (1997). (1986).

80. See generally, RUTH FADEN ET AL., A HISTORY AND THEORY OF INFORMED CONSENT

81. Olmstead v. United States, 277 U.S. 438,478 (1928) (Brandeis, J., dissenting); see Union Pacific Railway v. Botsford, 141 U.S. 250, 251 (1891) ("No right is held more sacred, or is more carefully guarded at common law, than the right of every individual to the possession and control of his own person ... 'to be let alone."').

82. Schloendorff v. Society of the N.Y. Hosp., 105 N.E. 92, 93 (N.Y. 1914). 
importance of rights to bodily integrity and personal autonomy, both crucial aspects of the consent doctrine. ${ }^{83}$

These rights are not absolute. In a few limited situations, informed consent is not required. ${ }^{84}$ Because a delay in treatment may jeopardize the patient's life or health, and because the patient may be comatose or delirious, consent is not always required in emergency situations. ${ }^{85}$ Physicians may also withhold decision-making information when, in their estimation, such information would cause severe distress for the patient. ${ }^{86}$ Patients may also waive their right to consent. Furthermore, patient consent is not required when that individual lacks decision-making capacity; instead, a surrogate's decision is sought. $^{87}$

Clinical standards for decision-making capacity are not identical to legal standards for competence. From a clinical perspective, ethicists explain that physicians should be sure their patient appreciates the nature of their medical situation (understanding the prognosis, the recommended care, alternatives and their risks and benefits). ${ }^{88}$. The decision should be stable over time, consistent with the patient's goals and values, and uninfluenced by delusions or hallucinations. ${ }^{89}$ From a legal perspective, courts do not always adhere to a uniform standard for determining competence, and one commentator has found that the courts deal with the issue "only in a cursory way."

In the more confined mental health care setting, the parameters of an individual's right to refuse care and the standards for determining his capacity to do so are less opaque. In his exhaustive treatise on the right to refuse mental health care, University of Miami School of Law Professor Bruce J. Winick explains that an individual becomes incompetent to make decisions when his "judgment is so affected by his mental illness that he lacks the capacity to make a well-reasoned, willful, and knowing decision concerning treatment." Also, patients deemed incompetent to make medical decisions

83. See Vacco v. Quill, 521 US 793, 798 (1997) ("Everyone, regardless of physical condition, is entitled, if competent, to refuse unwanted lifesaving medical treatment[.]"); Cruzan v. Director, Missouri Dept. of Health, 497 US 261, 278 (1990) ("The principle that a competent person has a constitutionally protected liberty interest [under the Due Process Clause] in refusing unwanted medical treatment may be inferred from our prior decisions." (citations omitted)).

84. Bernard Lo, Resolving Ethical DIlemmas: A Guide for Clinicians 31 (1995) [hereinafter ETHICAL DILEMMAS]; see also PAUL S. APPELBAUM, ET AL., INFORMED CONSENT: LEGAL THEORY AND ClINICAL PRACTICE (1987).

85. ETHICAL DILEMMAS, supra note 84, at 32.

86. Id.

87. Id.

88. Id. at 85 .

89. Id. at 32 .

90. Id. at 84 (citing ALAN MEISEL, THE RIGHT TO DIE (1995)).

91. WINICK, supra note 79, at 120 (quoting FLA. STAT. ch. 394.459(3)(a) (1995)). 
may not necessarily be universally incompetent. ${ }^{92}$ A patient may, for example, exhibit uncharacteristic clarity about his finances.

Decision-making capacity aside, the right to refuse care is limited in psychiatric settings. Many mentally ill patients meet clinical standards for incompetence and thus fall within an exception to informed consent. Furthermore, it is widely agreed that patients should not "rot with their rights on." That is, they should not be allowed to make unsound decisions about their care in the name of informed consent and personal rights. While hospitals must obtain consent when possible, either from the patient or his surrogate, they may not meet that ideal at all times. One author offered a dismal indictment of this system: "State hospital patients, whether voluntary or involuntary, are rarely provided an explanation of the presumed benefits and potential risks of drug treatment, are seldom asked for their consent and are often forcibly injected if they resist oral medication." 94 Of course, that sentiment reflects the research and analysis of one individual, and state hospital practices may have improved over the past decade.

Although consent from the incompetent patient may not be required for treatment, legal protections apply in common psychiatric situations. State laws protect citizens who face involuntary civil commitment, providing, for example, a right to a prompt hearing on the matter. ${ }^{95}$ Mentally ill inpatients may also be required to take psychotropic medications if they are dangerous or are incompetent. Ideally, a surrogate decision-maker or a court-appointed guardian has been consulted about treatment decisions. Liberty interests give way, but again, the government and the medical system aim to protect those interests as much as possible. ${ }^{96}$

Importantly, involuntary medication orders in the civil setting do not universally require a showing of immediate, tangible dangerousness. In New York, after a schizophrenic man who was noncompliant with his antipsychotic medications pushed a woman into an oncoming Manhattan subway car and killed her, the state legislature passed a law "joining nearly 40 other states in adopting a system of assisted outpatient treatment (AOT) pursuant to which psychiatric patients unlikely to survive safely in the community without super-

92. See Paul S. Appelbaum \& Thomas G. Gutheil, Clinical handbook of PSYCHIATRY AND THE LAW 220 (Williams \& Wilkins 2d ed. 1994) ("The mere presence of psychosis, dementia, mental retardation, or some other form of mental illness or disability is insufficient in itself to constitute incompetence.").

93. Paul S. Appelbaum \& Thomas G. Gutheil, "Rotting With Their Rights On": Constitutional Theory and Clinical Reality in Drug Refusal by Psychiatric Patients, 7 BulL. AM. ACAD. PSYCHIATRY \& L. 306 (1979).

94. WINICK, supra note 79, at 77.

95. See, e.g., CAL. WELF. \& INST. CODE $§ 5250$ (Deering 2005).

96. See, e.g., Addington v. Texas, 441 U.S. 418, 433 (1979) (holding that 14th Amendment due process protections require "clear, unequivocal and convincing evidence" in a civil commitment proceeding before involuntarily placing an individual in a mental hospital for an indefinite period of time). 
vision may avoid hospitalization by complying with court-ordered mental health treatment." ${ }^{\prime 97}$ In February 2004, the Court of Appeals of New York upheld the constitutionality of that law. ${ }^{98}$

Another recent state supreme court case emphasizes that an explicit showing of immediate dangerousness is not required to obtain a court order for treatment. In Steele v. Hamilton County Community Mental Health Board ${ }^{99}$ the Ohio Supreme Court held that a paranoid schizophrenic could be involuntarily medicated even though he was not dangerous to himself or others. Noting that he was incapable of giving informed consent and outlining the procedural due process required to issue the order for forced medications, the court found that the mentally ill, involuntarily committed patient could be medicated even if dangerousness was not a concern if the court found clear and convincing evidence that (1) the patient lacked capacity to give consent, (2) the medication was in his best interest, and (3) no less intrusive treatment would be as effective. The Steele court found authority to override the significant liberty interest at stake in the State's parens patriae power-the State's obligation to care for its citizens, especially those who, because of mental illness, are unable to care for themselves-as long as specified due process protections are met. ${ }^{100}$ This distinction is important: whereas the mentally ill criminal may be medicated involuntarily when he meets criteria that include dangerousness, the mentally ill citizen may be medicated without his consent if he is seriously disabled, even if he is not dangerous. Here, as in other situations, safeguards remain in place. For example, a court-appointed guardian may be asked to review the patient's record to determine if medication is in the patient's best interest.

Overall, then, patients with mental illness enjoy legal recognition of important treatment rights. Although they, like all patients, have a basic right to medical and psychiatric care and a right to refuse those interventions, incompetence may suspend some rights to refuse medical assistance. Civil

97. In the Matter of K.L., 806 N.E.2d 480, 482 (N.Y. 2004).

98. Id. at 483-86 (holding that New York Mental Hygiene Law $\S 9.60$, so-called "Kendra's Law," does not violate due process or other constitutional rights and is a reasonable exercise of the state's police power).

99. Steele v. Hamilton County Cmty. Mental Health Bd., 736 N.E.2d 10 (Ohio 2000).

100. Id. at 21. The court explained,

We have attempted to craft a decision that acknowledges a person's right to refuse antipsychotic medication, and yet recognizes that mental illness sometimes robs a person of the capacity to make informed treatment decisions. Only when a court finds that a person is incompetent to make informed treatment decisions do we permit the state to act in a paternalistic manner, making treatment decisions in the best interest of the patient.

Id. Both the parens patriae power and the police power have been cited in cases allowing the state to involuntarily medicate civilians. See Addington, 441 U.S. at 426 (holding that a state's parens patriae power allows it to care for citizens who are unable to take care of themselves and that the state "has authority under its police power to protect the community from the dangerous tendencies of some who are mentally ill."). 
commitment becomes an option, as does involuntarily administered antipsychotic medications. The State's parens patriae and police powers override individual liberty and support treatment that others, ideally a surrogate and a psychiatrist, feel to be in the patient's best interests. Because both law and ethics recognize the importance of the rights to bodily integrity and autonomy that are necessarily invaded with involuntary psychiatric treatment, states have important due process regulations in place to protect the degree of invasion and guarantee advocacy for the mentally ill patient. A guiding principle emerges - civil society values the importance of medical and psychiatric treatment for incompetent, mentally ill individuals.

\section{B. Criminal Rights Guarantees}

Criminals remain a vulnerable population, and criminals with mental illnesses are especially at risk. Notably, inmates have a constitutionally guaranteed right to health care, ${ }^{101}$ which includes psychiatric and psychological treatment. $^{102}$ District of Columbia Circuit Judge David Bazelon's seminal opinion in Rouse v. Cameron ${ }^{103}$ was a legal watershed that helped guarantee

101. Estelle v. Gamble, 429 U.S. 97, 104 (1976) (establishing that prisoners have a basic constitutional right to medical treatment and defining the standard for constitutional violations as "deliberate indifference to serious medical needs"); see also Farmer v. Brennan, 511 U.S. $825,839,847$ (1994) (holding that prison officials may be held liable under the Eighth Amendment for denying humane conditions of confinement only if the official had actual knowledge that inmates faced a substantial risk of serious harm and he disregards that risk by failing to take reasonable measures to abate it. That is, the officials must have "consciously disregard[ed]' a substantial risk of serious harm" to the prisoners.).

102. See Bowring v. Godwin, 551 F.2d 44, 47-48 (4th Cir. 1977).

We therefore hold that Bowring (or any other prison inmate) is entitled to psychological or psychiatric treatment if a physician or other health care provider, exercising ordinary skill and care at the time of observation, concludes with reasonable medical certainty (1) that the prisoner's symptoms evidence a serious disease or injury; (2) that such disease or injury is curable or may be substantially alleviated; and (3) that the potential for harm to the prisoner by reason of delay or the denial of care would be substantial. The right to treatment is, of course, limited to that which may be provided upon a reasonable cost and time basis and the essential test is one of medical necessity and not simply that

Id. which may be considered merely desirable.

103. Rouse v. Cameron, 373 F.2d 451 (D.C. Cir. 1966). Charles C. Rouse was involuntarily committed to a psychiatric facility after he was found not guilty by reason of insanity of carrying a dangerous weapon, which was a misdemeanor. He filed a habeas corpus petition and lost at the district court level because the court found that its jurisdiction was limited to the question of insanity, not whether the petitioner was receiving psychiatric treatment, as he had argued. On appeal, Judge Bazelon noted that the "principal issues raised by this appeal are whether a person involuntarily committed to a mental hospital on being acquitted of an offense by reason of insanity has a right to treatment that is cognizable in habeas corpus, and if so, how violation of this right may be established." Id. at 452. That court found that institutionalization without treatment was little different from incarceration, and that the period of confinement was significant-it could extend indefinitely. The court also noted that because Congress authorized 
rights to such care via statutory interpretation. The Rouse court extended the "right to treatment" idea that Congress established in its 1964 Hospitalization of the Mentally Ill $\mathrm{Act}^{104}$ to those who were involuntarily institutionalized per court order in a criminal proceeding. ${ }^{105}$ These hard won gains are crucial in the criminal setting because so many individuals entangled with the justice system are mentally ill and inmates cannot seek care on their own. ${ }^{106}$

Indeed, psychiatric illness and incarceration are familiar bedfellows. ${ }^{107}$ It is difficult to know which came first, the illness or the crime, but it is clear (in perhaps a gross understatement) that " $[t]$ he institution itself is not conducive to good mental health." 108 In 1999, the Justice Department estimated that sixteen percent of state and federal prisoners suffered from schizophrenia, bipolar disorder and/or major depression. ${ }^{109}$ In 2000, the American Psychiatric Association estimated that twenty percent of prisoners had a serious mental illness, with up to five percent of those individuals experiencing active psychosis at any particular time. ${ }^{110}$ A 2004 Human Rights Watch report

the 1964 Hospitalization of the Mentally Ill Act, which entitled mentally ill individuals hospitalized in public facilities to medical and psychiatric treatment, it could avoid constitutional questions about the right to treatment. In all, the court held that a right to treatment existed, and that institutions were required to make a "bona fide effort" to improve and cure the patient. Id. at 456.

104. D.C. CODE ANN. § 21-562 (2005).

105. For general discussion on the inception of this right to treatment, see THE RIGHT TO TREATMENT: A SYMPOSIUM (Donald S. Burris ed., 1969).

106. Although prisoners have a right to care, securing a particular right does not necessarily make it a reality. For a detailed analysis of the disturbing nature of incarceration and psychiatric

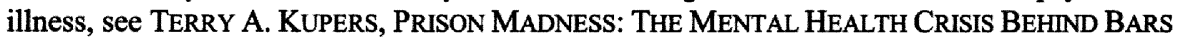
AND WHAT WE MUST Do ABOUT IT (1999). Kupers, a psychiatric expert who has testified in various class action lawsuits contesting the conditions of confinement and the quality of psychiatric and medical care available in prisons, describes the prison conditions that lead the sane to become insane and the insane to become considerably worse, noting that mental health treatment is "grossly deficient" and that prison conditions are "increasingly harsh." Id. at xvi.

107. For an epidemiologic approach to quantifying mental illness in the prison system, see NATHANIEL J. PALLONE, MENTAL Disorder AMONG PRISONERS: TOWARD AN EPIDEMIOLOGIC INVENTORY (1991).

108. Curtis Prout \& Robert N. Ross, Care and Punishment: The Dilemmas of PRISON MEDICINE 216 (1988). ("Prison life is enough to drive anyone crazy. The boredom, deprivation, isolation, and alienation make even the simplest forms of gratification difficult. For these reasons all but the most passive inmates are deeply angry.") Id. at 208.

109. Paula M. DitTon, U.S. Dep'T of Justice, NCJ 174463, Mental Health TreatMENT OF INMATES AND PROBATIONERS (July 1999) (discussing the scope of mental illness in prisons and finding that sixteen percent of state prison inmates, seven percent of federal inmates, and sixteen percent of those in local jails reported either a mental condition or an overnight stay in a mental hospital. The study also provides detailed statistics about mental illness, breaking down the data about crime and incarceration by race, gender and age).

110. Fox Butterfield, Study Finds Hundreds of Thousands of Inmates Mentally Ill, N.Y. TIMES, Oct. 22, 2003, at A14; see also H. Richard Lamb \& Linda E. Weinberger, Persons with Severe Mental Illness in Jails and Prisons: A Review, 49 PSYCHIATRIC SERVICES 483, 483 (1998) ("Clinical studies suggest that six to 15 percent of persons in city and county jails and 10 to 15 percent of persons in state prisons have severe mental illness."). 
estimated that "as many as one in five of the 2.1 million Americans in jail and prison are seriously mentally ill, far outnumbering the number of mentally ill who are in mental hospitals." 111 Jails and prisons have turned into de facto mental health hospitals, something that no one involved with mental health or the prison system ever wanted.

Just as the right to refuse medical care follows the right to receive medical care in the civil setting, these rights travel together in the criminal arena as well. Interestingly, "a dramatic transformation has occurred in the law pertaining to mental patients and prisoners. In the past 20 years, the battleground has shifted to litigation on behalf of these groups asserting various provisions of the Constitution as restrictions on unwanted imposition of treatment." 112 Clearly, from a constitutional perspective, inmates have a significant due process interest in avoiding unwanted antipsychotic medication, but that right is not absolute. ${ }^{113}$ For example, California recognizes that inmates have "a fundamental right against enforced interference with their thought processes, states of mind, and patterns of mentation ...."114 In order to balance that right with the need for psychiatric care, California requires a court order to compel medication, and to receive that order, the health care team must show that the proposed therapy would be beneficial, a compelling state interest supports its administration, no less onerous alternative therapies are available, and the therapy follows accepted medical-psychiatric practice. ${ }^{115}$

The constitutional limits on a prisoner's right to refuse antipsychotic medications have been increasingly defined. In Washington $v$. Harper, ${ }^{116}$ the Supreme Court held that a state could "treat a prison inmate who has a serious mental illness with antipsychotic drugs against his will, if the inmate is dangerous to himself or others and the treatment is in the inmate's medical interest." 117 The Harper Court found that the need for safety and order in the prison system, coupled with the state's obligation to provide appropriate medical care for its prisoners, justified invading a prisoner's "significant liberty interest in avoiding the unwanted administration of antipsychotic drugs ."118 Notably, the Court emphasized deference to the medical professionals who determine treatment plans because they "possess, as courts do not, the requisite knowledge and expertise to determine whether the drugs should

111. Butterfield, supra note 110, at A14 (reporting on HUMAN RIGHTS WATCH, ILLEQUIPPED: U.S. PRISONS AND OFFENDERS WITH MENTAL ILLNESSES (2003)).

112. WINICK, supra note 79, at 130.

113. See Kansas v. Hendricks, 521 U.S. 346, 356 (1997); United States v. Salerno, 481 U.S. 739, 750-51 (1987); Youngberg v. Romeo, 457 U.S. 307, 320 (1982).

114. CaL. PENAL CODE $\$ \S 2670-2680$ (Deering 2005).

115. CAL. PENAL CoDE $\$ 2679$ (b) (Deering 2005).

116. Washington v. Harper, 494 U.S. 210 (1990).

117. Id. at 227.

118. Id. at 221; see also Riggins v. Nevada, 504 U.S. 127, 135 (1992) (holding that the state may forcibly administer antipsychotic medication to a prisoner or criminal defendant despite his liberty interest in some circumstances if the medication is medically appropriate, as determined by a physician). 
be used in an individual case." 119 The Harper inquiry, asking for a finding of both dangerousness and medical appropriateness, has become a standard for the involuntary medication of mentally ill inmates. Harper had the concomitant effect of altering physicians' behavior - that is, physicians could follow the standard of care only if the inmate met the test for dangerousness, not if he were simply mentally ill or gravely disabled and incompetent to make healthcare decisions, as in the civil setting. The criminal situation, in that sense, created a higher standard for invading individual liberty interests.

However, the Supreme Court altered the contours of the right to refuse psychotropic medications in a related situation-the trial setting-in Sell v. United States. ${ }^{120}$ In Sell, the Court asked whether the Constitution allows the government to medicate a psychotic defendant involuntarily with psychotropic medications to render him competent to stand trial for nonviolent but serious white collar crimes. The defendant, Dr. Charles Thomas Sell, a dentist with a long history of psychosis who was arrested for fraud, initially presented a danger to himself and others during his pretrial detention. Medication was felt to be appropriate by his hospital physicians, but he refused to take such drugs. He remained incompetent to stand trial, even after a rather lengthy detention. Since the State intended to medicate him so he could stand trial, the case presented a new question about the appropriateness and constitutionality of involuntary medication.

After revisiting the weighty liberty interests at stake in the forced medication context, the Court held that the Constitution allowed the government to medicate an individual, in rare circumstances, for the overlapping purposes of treating illness and creating competence to stand trial. The Court explained that the exact purpose of the medication was inapposite:

A court need not consider whether to allow forced medication for that kind of purpose [rendering the defendant competent to stand trial], if forced medication is warranted for a different purpose, such as the purposes set out in Harper related to the individual's dangerousness, or purposes related to the individual's own interests where refusal to take drugs puts his health gravely at risk. There are often strong reasons for a court to determine whether forced administration of drugs can be justified on these alternative grounds before turning to the trial competence question. ${ }^{121}$ 
The Court found that "the Constitution permits the Government involuntarily to administer antipsychotic drugs to a mentally ill defendant facing serious criminal charges in order to render that defendant competent to stand trial," 122 but the Court set strict guidelines that balance government needs. Specifically, medication is allowable "only if the treatment is medically appropriate, is substantially unlikely to have side effects that may undermine the fairness of the trial, and, taking account of less intrusive alternatives, is necessary significantly to further important governmental trial-related interests." However, the Court held that involuntary medication was not appropriate in the Sell circumstance because the lower courts did not consider the trialrelated side effects and risks of the drugs, as well as the lengthy nature of Sell's current confinement. Hypothetically, though, it is possible to involuntarily medicate a non-dangerous defendant with antipsychotic drugs in order to render that individual competent to stand trial, if, along with the other Sell factors, such treatment is medically appropriate. ${ }^{124}$ Today, no court has extended Sell beyond the competency-for-trial setting. Still, the dangerousness requirement regarding forced medication in the criminal context may have been eviscerated, at least when creating competence to stand trial.

Until Sell, the standard for involuntary medication in criminal settings remained distinct from the civil standard, but this case represents a departure from that rule. Dangerousness aside, teaching of Sell is that an inquiry into the State's or defense's motivation regarding medication is unimportant when the defendant's situation falls under Harper or when the defendant "puts his

122. Id. at 179.

123. $I d$.

124. United States v. Gomes, 305 F. Supp. 2d 158 (D. Conn. 2004) (granting the government's request for involuntary antipsychotic treatment of a defendant with a grandiose and persecutory type of delusional disorder to stand trial on the felony charge of possessing a firearm with a felony record). Interestingly, the court found that since the Sell criteria were met, a defendant who was neither dangerous nor gravely disabled could be medicated in order for him to stand trial. The court did note, as part of its Sell analysis, that medication was medically appropriate to treat his delusional disorder, so the decision to medicate essentially turned upon what psychiatrists determined to be appropriate care.). Other courts have considered similar situations but have not found the Sell criteria to be met. The gravity of the criminal charge seems to be a definitive factor for courts. See, e.g., United States v. Dumeny, 295 F. Supp. 2d $131,131-32$ (D. Me. 2004) (denying the government's request to involuntarily medicate the defendant to restore his competency for trial and finding that the state interest in adjudicating the charge of "possession of firearms by a person previously committed to a mental health institute" was insufficient to overcome the defendant's liberty interests); United States v. Miller, 292 F. Supp. $2 d 163$ (D. Me. 2003) (denying medication-for-trial request and finding no important government interest at stake, an inadequate showing of medical appropriateness, and an inadequate consideration of the side effects of antipsychotic medications); United States v. Evans, 293 F. Supp. 2d 668 (W.D. Va. 2003) (finding that although treatment was medically appropriate, the importance of rendering a defendant competent to stand trial on a charge of forcibly intimidating and interfering with a government employee while she discussed the status of his overdue housing loan did not outweigh this non-dangerous, non-gravely disabled individual's right to be free from antipsychotic medications). 
health gravely at risk."125 The question of the State's motivation becomes irrelevant.

\section{Special Considerations for Death Row}

Assuming that mental illness has not preceded incarceration, it is difficult to stay free of symptoms of mental illness in prison, and the uniquely arduous conditions on death row make clinging to clarity extremely challenging. Estimates about the number of insane inmates awaiting execution vary. Researchers calculate that roughly forty to seventy percent of death row inmates are psychotic. ${ }^{126}$ A 2003 report from the British Broadcasting Company on mentally ill death row inmates in America asserts that approximately "ten percent of the 3,500 prisoners on death row are regarded as insane."127 Given the psychological pressure of waiting for one's execution day to arrive coupled with the miserable conditions in many prisons, ${ }^{128}$ it is somewhat astonishing that the fraction of psychotic inmates does not approach one hundred percent. ${ }^{129}$ Stanley Williams, a San Quentin Death Row inmate who has written about life and psychosis at that institution, remarked, "Prison is a place where grown men have gone insane. It is a place where men have been

125. Sell, 539 U.S. at 182.

126. See RoBERT JOHNSON, DEATH WORK: A STUDY OF THE MODERNEXECUTION PROCESS 50 (1990) (estimating that seventy percent of death row inmates suffer from mental illnesses); Dorothy Otnow Lewis et al., Neuropsychiatric, Psychoeducational, and Family Characteristics of 14 Juveniles Condemned to Death in the United States, 145 AM. J. PSYCHIATRY 584 (1988) (fifty percent of juveniles on death row whom the author surveyed suffered from some form of psychosis); Dorothy Otnow Lewis et al., Psychiatric, Neurological, and Psychoeducational Characteristics of 15 Death Row Inmates in the United States, 143 AM. J. PSYCHIATRY 838 (1986) (forty percent of surveyed adult death row inmates suffered from chronic psychosis).

127. ABC Online, Foreign Correspondent: U.S.A.-Death Row Medication, at http://www.abc.net.au/foreign/stories/s894253.htm (last visited Apr. 17, 2005) (on file with the Indiana Health Law Review) (providing a synopsis of BBC: U.S.A.-Death Row Medication (BBC television broadcast Aug.7, 2003)).

128. See Judge Orders State to Clean Death Row, CH. TRIB., May 22, 2003, at 20 (reporting that U.S. Magistrate Jerry A. Davis, in an opinion about death row conditions, berated the government: "No one in a civilized society should be forced to live under conditions that force exposure to another person's bodily wastes." Davis ruled that harsh conditions were contributing to a high rate of mental illness among prisoners and ordered Mississippi prisons to reform.).

129. The number of death row prisoners suffering from severe mental illnesses may, in fact, be quite high. See David Freedman \& David Hemenway, Precursors of Lethal Violence: A Death Row Sample, 50 Soc. Sci. \& Med. 1757 (2000). The authors surveyed sixteen death row inmates in California and found some degree of impairment in every case, including fourteen with Posttraumatic Stress Disorder, thirteen with severe depression, and twelve with traumatic brain injury. 
killed and where some have even killed themselves. Prison is hell. This I know." 130

Insanity, as the Singleton saga makes clear, can become an obstacle to execution. Historically, the common law barred killing the insane. ${ }^{131}$ The celebrated commentator Blackstone argued that such killings were "savage and inhumane" and that they eliminated the possibility that the convicted criminal could assist in advocating for a stay of his own execution. ${ }^{132} \mathrm{Sir}$ Edward Coke advanced humanitarian reasoning as well as concerns about losing the deterrent value of the execution if the State put the insane to death. To Coke, the executed prisoner should serve as an example, "but so it is not when a mad man is executed, but should be a miserable spectacle, both against Law, and of extream [sic] inhumanity and cruelty, and can be no example to others." 133 Other reasons for exempting the insane from execution include the lack of retributive value - if the prisoner fails to connect his crime with his punishment, the punishment becomes meaningless-along with the spiritual need to be aware of one's impending death in order to properly prepare for it.

Although the prohibition against executing the insane dates back hundreds of years, a constitutional limit on executing prisoners with mental illnesses is relatively new. In 1897, the Supreme Court held in Nobles $v$. Georgia $^{134}$ that hearings were an unnecessary part of due process protections for a mentally incompetent prisoner. Other courts and legislatures responded to that holding with a nod toward the insane by not executing such individuals, finding that there was no legal reason to do so. ${ }^{135}$ The Court revisited questions of competency and execution in Ford $v$. Wainwright,${ }^{136}$ holding that the Eighth Amendment's bar against cruel and unusual punishment precluded the State from executing an inmate who carried a diagnosis of paranoid schizophrenia and did not understand that he was to die because of his crime. The

130. Greg Lefevre, Inmate Nominated for Nobel Prize, CNN.COM, Dec. 7, 2000 (quoting STANLEY WilliamS, LIFE IN PRISON (2001)), at http://www.cnn.com/2000/US/12/02/death. row.nobel/index.html (last visited Apr. 17, 2005) (on file with the Indiana Health Law Review). For another account of the troubling conditions on death row, see JOHNSON, supra note 126.

131. See, e.g., ALISON WEIR, HENRY VIII: THE KING AND HIS COURT (2001). Biographer Weir notes that at one point during his reign, King Henry VIII "had demanded that Parliament pass an act making it lawful for him to execute an insane person who had committed treason" in order to execute the extremely distressed Lady Rochford. Id. at 450 . The existence of such a request illustrates the apparent illegality of executing the insane.

132. 4 WILLIAM BLACKSTONE, COMMENTARIES *24-*25 ("[A]nd if, after judgment, he becomes of nonsane memory, execution shall be stayed: for peradventure, says the humanity of the English law, had the prisoner been of sound memory, he might have alleged something in stay of judgment or execution.").

133. Ford v. Wainwright, 477 U.S. 399, 407 (1986) (quoting E. COKE, 3 INSTITUTES 6 (6th ed. 1680)).

134. Nobles v. Georgia, 168 U.S. 399,409 (1897).

135. Bruce A. Arrigo \& Christopher R. Williams, Law, Ideology, and Critical Inquiry: The Case of Treatment Refusal for Incompetent Prisoners Awaiting Execution, 25 NEW ENG. J. ON CRIM. \& CIV. CONFINEMENT 367, 367-68 (1999).

136. Ford v. Wainwright, 477 U.S. 399 (1986). 
Court reasoned that executing the insane would depart from legal tradition, offend humanity, and fail to meet the State's retributive and deterrence goals. It was unmoved by a singular rationale for this ban, but rather, it noted, "Whether its aim be to protect the condemned from fear and pain without comfort of understanding, or to protect the dignity of society itself from the barbarity of exacting mindless vengeance, the restriction finds enforcement in the Eighth Amendment." 137 Because no state sanctioned executing the insane, the holding was largely uncontroversial.

While the Ford majority did not explicitly define how to determine competence for execution, lower courts have looked to Justice Lewis Powell's concurrence in Ford for the articulation of a standard. Powell culled the standard from existing state statutes that, on the whole, focused on understanding the nature and purpose of the punishment. ${ }^{138}$ As Justice Thurgood Marshall noted, "[i]t is no less abhorrent today than it has been for centuries to exact in penance the life of one whose mental illness prevents him from comprehending the reasons for the penalty or its implications." 139 Powell noted that some states "have more rigorous standards, but none disputes the need to require that those who are executed know the fact of their impending execution and the reason for it." ${ }^{" 140} \mathrm{He}$ wrote that the Constitution forbids the execution "only of those who are unaware of the punishment they are about to suffer and why they are to suffer it."141 Powell's test-whether a condemned person understands the nature of and reason for his punishment-is the legacy of Ford and the standard generally used to determine competence for execution. ${ }^{142}$

137. Ford, 477 U.S. at 410.

138. See, e.g., GA CODE ANN. $\S 17-10-60$ (2004) (convict must understand the punishment and why it is to be imposed on him).

139. Ford, 477 U.S. at 417.

140. Ford, 477 U.S. at 422 (Powell, J., concurring) (footnote omitted). But see Ford, 477 U.S. at 435 (Rehnquist, J., dissenting) ("I find it unnecessary to 'constitutionalize' the already uniform view that the insane should not be executed, and inappropriate to 'selectively incorporate' the common-law practice.").

141. Ford, 477 U.S. at 422 (Powell, J., concurring).

142. It has been criticized as a low threshold, one that the Court should clarify. See Rector v. Bryant, 501 U.S. 1239 (Marshall, J., dissenting from denial of certioriari). Justice Marshall explained,

In Ford v. Wainwright, 477 U.S. 399 (1986), this Court recognized that "the Eighth Amendment prohibits a State from carrying out a sentence of death upon a prisoner who is insane." Id. at 409-410. The full Court, however, did not attempt a comprehensive definition of insanity or incompetence in this setting. This petition presents the question whether a prisoner whose mental incapacity renders him unable to recognize or communicate facts that would make his sentence unlawful or unjust is nonetheless competent to be executed. Because Ford leaves this question unanswered, and because this is an important and recurring issue in the administration of the death penalty, I would grant the petition.

Id. at 1239 
Before Charles Singleton's most recent appeal, only Louisiana had adjudicated a case where forced antipsychotic medications and the death penalty clashed. In State v. Perry, ${ }^{143}$ an insane inmate on Louisiana's Death Row challenged whether the State could forcibly medicate him with antipsychotics for the sole and explicit purpose of restoring his competence for execution. Importantly, the issue of medication arose in the execution context, and the State failed to prove that medication furthered "both the best medical interest of the prisoner and the state's own interest in prison safety." 144 Rather, the State aimed to make Perry lucid enough to die.

The Louisiana Supreme Court held that the State's "medicate-toexecute" scheme failed to advance a compelling state interest, violated Perry's rights to bodily integrity and to refuse medical care, and fell short of the Harper requirements. ${ }^{145}$ The Perry court found that involuntary medication, in this context, violated the cruel and unusual punishment clause of Louisiana's state constitution. ${ }^{146}$ The court stayed the death sentence until Perry could become competent without antipsychotic medication. Louisiana's rule about antipsychotic medications in the context of executions seems to be that an execution cannot go forth until the prisoner has regained his sanity and is no longer taking antipsychotic medications. ${ }^{147}$

143. State v. Perry, 610 So. $2 d 746$ (La. 1992).

144. According to the Perry court, " $[t]$ he state in Perry's case has made neither showing but seeks forcible medication of a prisoner by court order as an instrument of his execution." $I d$. at 751. However, there is some confusion in the case on this issue. Justice Marcus, in his dissenting opinion, noted that "the trial court found Perry to be a danger to others, and the sanity commission was of the opinion that psychotropic medication relieved the symptoms of Perry's disorder with minimal side effects and was in his best medical interest." Id. at 777 (Marcus, J, dissenting). If the majority had agreed with that opinion, Perry and Singleton would address similar issues.

145. Id. at 755 .

146. See also Singleton v. State, 437 S.E.2d 53, 62 (S.C. 1993) (holding that "justice can never be served by forcing medication on an incompetent inmate for the sole purpose of getting him well enough to execute.").

147. The court found Perry to suffer from an "incurable schizoaffective disorder," a disease that, according to the court, will never be cured or quelled. Perry, 610 So. $2 \mathrm{~d}$ at 748 . Further, the court found that involuntary medication in this context undermines the patient's trust in his physician, places the state's goals above patient well-being, which, the court said, creates an incongruous position for physicians, and gives rise to implementing the death penalty in an arbitrary and capricious way. Essentially, Louisiana would suspend death sentences for anyone with a severe mental illness that requires antipsychotic medications for treatment. Id. The court also argued that the "aggregate of conditions surrounding the physician's determination of the prisoner's mental capacity at the time of execution does not yield room for well-informed and dispassionate medical judgment." Id. at 753. States obviously differ in their conclusions on this issue. See, e.g., In re Emergency Amendment to Florida Rules of Criminal Procedure (Rule 3.811, Competency to be Executed), 497 So. 2d 643, 644 (Fla. 1986)

A prisoner who, because of psychotropic medication, has sufficient ability to understand the nature and effect of the death penalty and why it is to be imposed upon him or her shall not be deemed incompetent to be executed simply because his or her satisfactory mental condition is dependent upon such medication. 


\section{SINGLETON'S SITUATION AND THE PSYCHIATRIST's DILEMMA}

From the preceding discussion, it is clear that as a matter of constitutional law, a psychotic inmate's liberty interest in bodily integrity yields to neuroleptic medication if that inmate both poses a danger to himself or others and medicating him would be in his medical interest. ${ }^{148}$ It is also clear that individuals must be competent to face execution. ${ }^{149}$ It is less clear what happens when these rules collide.

\section{A. Singleton v. Norris-Where Harper Meets Ford}

The facts of Singleton illustrate its uniqueness in constitutional law. It was the first federal case to link involuntary antipsychotic medications with competence for execution. Singleton, a death row inmate who became psychotic during his incarceration, met the Harper requirements for involuntary medication and would have been medicated but for his death sentence. Because the antipsychotic medications effectively rendered him Ford competent for execution, ${ }^{150}$ the problem became a syllogism. Singleton needed

Id.

148. Washington v. Harper, 494 U.S. 210 (1990).

149. Ford v. Wainwright, 477 U.S. 399 (1986).

150. But see Singleton v. Norris, 319 F.3d 1018, 1034 (Heaney, J., dissenting) (recounting psychiatrist Dr. Mrad's opinion that Singleton may not be competent even when medicated.) A psychiatrist who examined Singleton said that he might be psychotic even while medicated. According to Judge Heaney,

Singleton admitted to having continued hallucinations, and "occasionally referred to himself as God or God-like and on a few occasions referred to himself as the Holy Spirit." (Mrad Dep. at 21.) Regarding Singleton's understanding of his punishment, Mrad stated: "I asked him if he was God, how could he be executed, and he slapped his arm and said I've got this. My understanding referring to a body. He could be - he could be executed and that it would-and I think he knew that the reason for the execution would be conviction for the murder of Mary Lou York and by that I believed he had a factual understanding. He could recite- basically recite basic facts that he would be-what the sentence was and why he would be given that sentence. The other part of it, the rational understanding I think was-has more to do with does he actually understand what this means, not only can he say it but does he actually understand what this means and what it means as applied to him, and it was not at all clear to me that he did. His thinking was so disorganized. He made these frequent comments about being the Holy Ghost or Holy Spirit. He talked about a-some beliefs about a parallel world, about being - an execution just being stopping breathing and then you start up again somewhere else and that - there was some statement made about correctional officers. Execution correctional officers stop you from Id. at 1032. breathing and then the judge can do something to start it up again.

He also mentioned that Singleton was writing a book per God's request, that he and a particular saint were on a mission against homosexuals, and that "Sylvester Stallone and Arnold 
medications to treat his psychosis. When medicated, he was competent to be executed. Yet, death was a fate he wished to avoid for a long period of time since his conviction. Therefore, could the State involuntarily medicate Singleton, since he was a danger to himself and others, knowing that those medications would have the likely effect of rendering him Ford competent for execution? ? $^{151}$

In Singleton v. Norris, ${ }^{152}$ a closely divided en banc panel of the Eighth Circuit Court of Appeals answered that question in the affirmative. The core issue, the Eighth Circuit said, was whether neuroleptics were medically appropriate. It explained that:

[i]n the circumstances presented in this case, the best medical interests of the prisoner must be determined without regard to whether there is a pending date of execution. Thus we hold that the mandatory medication regime, valid under the pendency of a stay of execution, does not become unconstitutional under Harper when an execution date is set. ${ }^{153}$

In a six-to-five decision, the majority held that the State does not violate the Constitution if it executes a prisoner involuntarily medicated under Harper, and it may forcibly administer antipsychotics to a death row inmate who is scheduled for execution. Some observers called it a victory for states' rights. ${ }^{154}$ Others saw it as a loss for prisoners' autonomy. ${ }^{155}$ Despite its implications, the United States Supreme Court declined to hear the case on appeal. ${ }^{156}$ Because it crystallizes an ongoing controversy in law and medical ethics, Singleton presents an important question for physicians and society.

Schwarzenegger were somewhere between this universe and another one and were trying to save him." Id.

151. Although Singleton presented a novel legal issue, some prescient commentators anticipated it. See Arrigo \& Williams, supra note 135, at 379. Arrigo and Williams noted:

Interestingly $[$ Ford $]$ does not guarantee that mentally ill prisoners awaiting execution and asserting a right to refuse treatment would, in all instances, be protected from capital punishment, despite Eighth and Fourteen Amendment safeguards. Indeed, consistent with the holding in Harper, to the extent that an inmate presented a dangerous risk to other prisoners, to correctional staff, and to himself, forced drug therapy could be constitutionally ordered. This result could follow, notwithstanding an inmate's liberty interest in refusing involuntary psychiatric treatment and in avoiding mental punishment. This weighty matter Id. has yet to be addressed by the U.S. Supreme Court.

152. Singleton v. Norris, 319 F.3d 1018 (8th Cir. 2003), cert. denied, 540 U.S. 832 (2003). 153. Id. at 1026.

154. Adam Liptak, State Can Make Inmate Sane Enough to Execute, N.Y. Times, Feb. 11, 2003, at A1.

155. Id.

156. Singleton v. Norris, 540 U.S. 832 (2003). 


\section{B. Is it Legal and Ethical to Treat Singleton?}

Unfortunately, even with the legal advances of the last forty years, adequate mental health care in prison remains elusive. One recent report said it is "almost non-existent." 157 Although Singleton turns on the right to refuse mental health care, this issue and the consequent dilemmas it creates should not overshadow the very real and pressing problems that many inmates face, like substandard mental health care and higher rates of mental illness among female inmates. ${ }^{158}$ It is a system overwhelmed by need. This Article's focus on the right to refuse guaranteed mental health care is somewhat ironic in the context of scarce services. It is but a sliver of the larger picture, and it should not cloud the overwhelming need for psychiatric services facing so many incarcerated individuals. With that disclaimer, the analysis of Singleton follows.

\section{Arguments Against Treatment}

Judge Heaney's dissenting opinion in Singleton offered an excellent summary of the strongest arguments against involuntary treatment. ${ }^{159}$ First, he posed an "artificial competence" theory. That is, a medicated inmate will never meet the Ford standard for competence because treatment only masks psychotic symptoms. The inmate is never actually cured. As Ronald Tabak, a New York-based attorney who has represented clients in death penalty cases, says, "If he [Singleton] is artificially made to be competent, then the situation is an oxymoron." 160 According to this argument, antipsychotic medications simply hide the psychosis. The patient is never cured, and his incompetency merely remains "muted" for the duration of his treatment. Under this view, antipsychotics interfere with the individual's ability to think and express himself, potentially implicating First and Sixth Amendment concerns, and the competency that follows their administration is false. Because treatment is not curative, the inmate is never truly competent.

157. Butterfield, supra note 110 , at A14 (reporting that a Justice Department investigation found that a Wyoming state penitentiary had a psychiatrist on duty only two days a month, and in Iowa, three psychiatrists were responsible for more than 8,000 inmates). For a discussion on the complexities of providing medications and medical care to a prison population, see CURTIS Prout \& Robert N. Ross, CARE AND PUNISHMENT: THE DILEMMAS OF Prison MEDICINE 162$68(1988)$.

158. DITTON, supra note 109, at 3 (finding mental illness among twenty-four percent of female State prison and local jail inmates).

159. Of the three dissenting opinions, two disagreed with the majority on procedural grounds; only Judge Heaney addressed the constitutional claims at length. Singleton, 319 F.3d at 1029 (Loken, J., concurring in part and dissenting in part); Singleton, 319 F.3d at 1030 (Heaney, J., dissenting in which Bright, J., McMillian, J., and Bye, J., join).

160. Drew, supra note 55. 
Second, Judge Heaney argued that the State's interest in exacting punishment undermined its interest in treatment. This view posits that Harper is a convenient excuse to medicate Singleton - the Government's only real goal is to carry out the punishment that it had been waiting to mete out for the better part of two decades. Third, the Judge remained unconvinced that forced medical treatment was in Singleton's medical interest when it may ultimately facilitate his execution. Proponents of this view explain that death is never in a patient's "medical interests," and therefore, forcing Singleton to take medications that will likely render him Ford competent fails to meet the second prong of Harper. As Georgetown University law professor and psychiatrist Dr. M. Gregg Bloche put it, treating Singleton represents "a parody of physicians' failure to treat the whole patient. The notion that you can view treatment as medically appropriate when the immediate legal consequence of treatment success is death is out of "Alice in Wonderland."'161 It is, he says, the equivalent of saying that the operation was successful even though the patient died. ${ }^{162}$

Finally, Judge Heaney rebuked the majority for creating a terrible dilemma for the medical profession - to treat, understanding that execution may result, or not treat, knowing that psychosis awaits the inmate. Judge Heaney concluded that the State's interest in protecting the integrity of the medical profession and alleviating its ethical dilemma argues for a permanent stay of execution. This argument claims that physicians are placed in an impossible bind that betrays their principles of medical ethics. Medicating Singleton, so the argument goes, conflicts with the medical profession's tenet to do no harm. The physician acts as the executioner's handmaiden. Essentially, his actions are the "but for" cause of the execution, and he kills the patient. As psychiatrist and author Paul S. Appelbaum explains, "[o]rdinarily when a person is suffering from psychosis, our impulse is to treat that person, to try to diminish their symptoms and diminish their suffering."163 In the Singleton case, he continued, "we're in a situation where the very treatment that we render, rather than helping our patients, has the probability of leading to greater harm, in fact, the ultimate harm of allowing them to be put to death." 164 Since the physician is now seen as an arm of the government's killing machine, arguments against physician participation in executions may

161. All Things Considered: Legal Dispute Over Whether a State can Force a Man Who is Psychotic to Take Medication to Make Him Legally Sane in Order to Execute Him (NPR broadcast, Feb. 12, 2003).

162. Id.

163. Nightline: Executing the Mentally Ill (ABC television broadcast, May 19, 1998).

164. Id. 
be invoked. ${ }^{165}$ Careful analysis reveals that these arguments fail. Not only is it legal to medicate Singleton, it is also ethically required.

\section{Arguments for Treatment}

\section{a. Singleton follows well-established constitutional law}

It is hardly debatable that Singleton adheres to the clear constitutional law on medicating insane inmates. In terms of the Harper inquiry, the record is unequivocal. Singleton was dangerous to himself and others in the prison setting when left off his medications. Singleton never actually debated this point. As the Arkansas Supreme Court found in Singleton's 1998 appeal, "[A] Harper decision was made by a three-person Medication Review Panel on August 18, 1997, that the State did have a legitimate reason to medicate Singleton without his consent, and that decision was not appealed by him to circuit court."166 Advocates for Singleton's position argue that Harper's second prong, the medical interests inquiry, fails in hindsight because medications lead to Ford competency-and execution cannot be in his medical interests. Because it presents a somewhat circular analysis, the question of medical appropriateness will be addressed in detail below.

It is also indisputable that Singleton met the Ford standard for competence. A panel of experts, Singleton's attorney, and the Eighth Circuit agree on this point. Opponents of this conclusion can only point to the artificial competence argument - an argument that simply proves too much. Many individuals live with chronic diseases like hypertension, epilepsy, depression, bipolar disorder, HIV, diabetes and asthma. Their medications, just like psychotropic medications, do not cure their illness. They only control its symptoms. Moreover, society does not consider epileptics who rely on medication to keep seizures at bay "artificially competent" to work or drive. As the American Psychiatric Association has argued, "The mental health produced by antipsychotic medication is no different from, no more inauthentic or alien to the patient than, the physical health produced by other medications, such as penicillin for pneumonia." ${ }^{167}$ Medicated citizens do not fall into a separate class with restricted legal privileges and consequences because they rely on pharmaceuticals to create physiologic normalcy. Even with emerging psychiatric symptoms, it is possible to meet the Ford standard. Notably, Ford does not require a cure or even the disappearance of all psychiatric symptoms. It

165. See, e.g., Alfred M. Freedman \& Abraham L. Halpern, The Erosion of Ethics and Morality in Medicine: Physician Participation in Legal Executions in the United States, 41 N.Y.L. SCH. L. REV. 169 (1996); Robert D. Truog \& Troyen A. Brennan, Sounding Board: Participation of Physicians in Capital Punishment, 329 NEW ENG. J. MED. 1346 (1993).

166. Singleton v. Norris, 964 S.W.2d 366, 368 (Ark. 1998).

167. Riggins v. Nevada, 504 U.S. 127, 141 (1992)(Kennedy, J., concurring) (quoting Brief for American Psychiatric Association as Amicus Curiae at 9). 
simply requires that the inmate understand the punishment and why he is to be punished.

Advocates for Singleton also assert that the Government's interest in medicating him was impure since it was motivated, at least in part, by the hope of executing him. The Eighth Circuit explicitly declined to examine the State's reasons for wanting to medicate Singleton and instead looked to the motivations of his treating physicians. If it had, it might have found, as the federal district court did, that "Singleton was not placed on medication to make him competent, so the State could execute him; rather, the court found he was being medicated to meet his medical needs." 168 Regardless, the Supreme Court's decision in Sell, issued just months after the Singleton decision, directly addressed the question of government motivation in involuntary medication cases. If the court finds a legitimate reason to medicate a defendant, it is not required to inquire into the State's intent. Even assuming the worst, that Arkansas purposely aimed to medicate Singleton to facilitate his execution, that inquiry becomes irrelevant under Sell given the legitimate reasons to medicate him. Although Sell considered medication in the context of a trial, the holding may apply in other situations.

In any event, even if the motivation inquiry were relevant in this case, it is clear that Singleton is not Perry. Singleton does not implicate an explicit, unequivocal medicate-to-execute scheme. As the Eighth Circuit explicitly noted, there was "no evidence in this record that the actions and decisions of the medical personnel involved were in any degree motivated by the desire, purpose or intent to make Mr. Singleton competent so that he could be executed." "W9 While the government made absolutely no Harper showing in Perry, the record notes that Singleton was medicated with antipsychotic drugs, on and off, for many years. He was dangerous and had been mentally ill long before questions about execution competency became pressing. Therefore, accusations that Singleton is about using the physician's tools to facilitate an execution are precisely wrong. ${ }^{170}$

168. Singleton, 964 S.W.2d at 370 (Glaze, J., dissenting).

169. Singleton v. Norris, 319 F.3d 1018, 1022 (8th Cir. 2003).

170. Although the Eighth Circuit was clear as to the question presented and the consequent holding, the national and international press mischaracterized the key issue. The New York Times Page One headline said, "State Can Make Inmate Sane Enough to Execute," and the opening sentence of that article read, "The federal appeals court in St. Louis ruled yesterday that officials in Arkansas can force a prisoner on death row to take antipsychotic medication to make him sane enough to execute." Liptak, supra note 154, at A1 (emphasis added). For other examples, see Dateline NBC: Crazy Like a Fox?, supra note 4. (asking, "But can the state force him to take medication to restore his sanity in order to kill him?"); All Things Considered, supra note 161 (reporting that " $[t]$ his week, a federal appeals court ruled that the state of Arkansas can forcibly medicate a death row inmate to make him sane enough to execute."); A New Insanity Defence, ECONOMIST, Mar. 1, 2003, at 31 (asking in its subtitle, "Can you treat an insane man just so that you can convict or execute him?"); Crazy Week, ARK. DEMOCRAT-GAZETTE, Jan. 11, 2004, at 76 (reporting that the Eighth Circuit Court of Appeals had "decided that [Singleton] might be treated in order to be killed"); Paul Greenberg, Time is Running Out and So is Sanity 


\section{b. Treatment is in Singleton's "medical interests"}

Before a court may order involuntary therapy, Harper's second prong requires that medication support an inmate's "medical interests," and the Singleton case ultimately turned on the definition of that phrase. The Singleton court found that "the best medical interests of the prisoner must be determined without regard to whether there is a pending date of execution."171 That court stood on firm legal ground.

Case law shows that courts have defined the phrase "medical interests" with an eye toward medical issues, not psychosocial or personal ones. How the inmate feels about medication, whether he would prefer not to continue with the judicial process, what his physician thinks about the judicial process - these questions are inapposite. Harper carefully limited its inquiry to medical therapy qua medicine. It did not include other interests the inmate may have had. The Court restricted its focus to the side effects of the various

in the Curious Case of Charles Singleton, ARK. DEMOCRAT-GAZETTE, Jan. 4, 2004, at 72 (imploring the governor to halt the execution and reporting that "the Eighth Circuit Court of Appeals agreed that the State of Arkansas was within its rights to forcibly medicate said defendant in order to render him sane enough to executed.").

The tone of the reporting conveyed the message that the State's (and its physicians') sole aim was execution, not treatment. This sentiment led to misunderstandings about the case. In the New York Times, letters to the Editor confused the issues and were generally off point. Dr. Deborah Young said, "We have fallen through the looking glass if it is now considered 'beneficial' to medicate a psychotic prisoner just long enough to declare him or her sane and then proceed to execution, presumably before the medication wears off." Deborah Young, Sanity and Execution: A Tale Worthy of Kafka, N.Y. TIMES, Feb. 14, 2003, at A30. Singleton met the standard for involuntary medication, and he would have been medicated even if the drugs failed to restore his competence but only served to make him less dangerous. Even the Chairman of the American Medical Association's Council on Ethical and Judicial Affairs seemed to misread the case, or else relied solely on the Times somewhat misleading report about it. Noting the American Medical Association's Code of Medical Ethics decree, that "physicians should not treat the prisoner for the purpose of restoring competence unless a commutation order is issued before treatment," he declared that "no doctor should participate in this process." Leonard J. Morse, Sanity and Execution: A Tale Worthy of Kafka, N.Y. Times, Feb. 14, 2003, at A30. Yet, Singleton is not Perry, and thus the critique is off base. And from the Arkansas Democrat-Gazette, a letter to the Editor was wrong on two counts, asking, "How can our legal system justify medicating back to sanity a person who was mentally ill at the time of a crime just for the purpose of execution?" Letters, ARK. DEMOCRAT-GAZETTE, Jan. 12, 2004, at 11. Singleton was not mentally ill in a legally meaningful way when he murdered York, and competency for execution was a side-effect of the medication, not its raison d'être. The media outlets mentioned here never clarified the issue. Readers deserve accuracy in reporting, especially when the contentiousness of the case turns on an exact reading.

Amidst the sea of journalists mauling the issues, CNN's Brian Cabell reported the case correctly: "In February 2003, the 8th U.S. Circuit Court of Appeals ruled that states may forcibly administer anti-psychotic medication to control a prisoner's behavior, even if doing so renders the prisoner eligible for execution." Brian Cabell, Arkansas Executes Mentally Ill Inmate, CNN.COM, Jan. 7, 2004, at http://www.cnn.com/2004/LAW/01/06/arkansas.executions/ (last visited Apr. 17, 2005) (on file with the Indiana Health Law Review).

171. Singleton, 319 F.3d at 1026. 
drugs, the standard for treatment of the illness outside of the penal setting, and less intrusive alternatives to quell the inmate's dangerousness. It was uninterested in the terms of his incarceration or what sanity would mean to the prisoner. In Sell, the Court revisited the "medical interests" question and offered further guidance as to the correct definition. It explained that when determining the appropriateness of involuntary psychotropic medication orders, "the court must conclude that administration of the drugs is medically appropriate, i.e., in the patient's best medical interest in light of his medical condition. The specific kinds of drugs at issue may matter here as elsewhere." "172 To date, no court has considered a possible legal ramification of competence, like execution, to be a meaningful aspect of the definition. The majority rule confines the inquiry strictly to clinical issues-looking to physicians' determinations about appropriate treatment, which include balancing the risks of side effects with the benefits of a particular medication. ${ }^{173}$ It appears, then, that the definition rests on issues that are precisely medical.

172. Sell v. United States, 539 U.S. 166, 181 (2003).

173. See United States v. Williams, 356 F.3d 1045, 1056 (9th Cir. 2004) (looking to "a medically-informed record" for decisions about involuntary antipsychotic medication in prison and during supervised release and noting that the evaluation of medical interests includes "timely evaluation of the supervise[e] by a medical professional, including attention to the type of drugs proposed, their dosage, and the expected duration of a person's exposure, as well as an opportunity for the supervisee to challenge the evaluation and offer his or her own medical evidence in response."); Dancy v. Gee, 51 Fed. Appx. 906, 908 (4th Cir. 2002) (affirming the district court's summary judgment for the government and finding that no violation of a federal inmate's civil or constitutional rights occurred during forced administration of antipsychotic medications because, in terms of the "medical interests" inquiry, "no medical evidence contradicting the judgments of the medical professionals" was presented. Hence, no triable issue of fact existed. Here, a paranoid schizophrenic inmate exhibited wildly inappropriate behavior, like throwing urine and feces at others, and was subsequently medicated involuntarily with psychotropic drugs. The treating psychiatrist determined such medications were "clinically appropriate" and "medically necessary" in light of the clinical situation.); United States v. Weston, 206 F.3d 9, 12 (D.C. Cir. 2000) (focusing the inquiry around "medical appropriateness" on treating psychiatrists' clinical recommendations); Jurasek v. Utah State Hosp., 158 F.3d 506, 513 (10th Cir. 1998) (following Harper to determine the constitutional floor for forced mental treatment in a civil context and looking to "medical best interests"); Fearance v. Scott, 56 F.3d 633, 642 (5th Cir. 1995) (denying stay of execution and habeas relief for a death row inmate taking psychotropic medications for "therapeutic purposes"); United States v. Brandon, 158 F.3d 947 (6th Cir. 1998) (following strictly medical considerations for the "medical interests" inquiry); Ashby v. Schneck, No. 94-3354, 1995 U.S. App. LEXIS 17154 (8th Cir. July 17, 1995) (adhering to a psychiatrist's findings about medical interests, which were strictly limited to medical issues); see also United States v. Gomes, 305 F. Supp. 2d 158, 168 (D. Conn. 2004) (looking to medical issues to answer the medical interests query-noting that the evaluating psychiatrists "considered the benefits and potential side effects and concluded that, on balance, treatment with medications was the indicated course of treatment"). But see Washington v. Harper, 494 U.S. 210, 245 n.11 (1990) (Stevens, J., dissenting) ("the qualitative judgment of what is a patient's best interest cannot be made without reference to his own preferences"). Even so, there is no indication from the Fuller court that the expanded inquiry must consider the inmate's or civilly committed individual's interest in avoiding legally sanctioned judicial proceedings or punishments. 
Essentially, courts confine their inquiry to what is medically indicated, deferring to doctors' assessment of clinically appropriate treatment, which, in turn, is guided by the standard of care. For acute agitation, the psychiatric course includes antipsychotic and antianxiety medications, like lorazepam and haloperidol, to achieve behavioral control with minimal side effects. ${ }^{174}$ High potency neuroleptics are also useful, and atypical or typical antipsychotics are important in long-term treatment to prevent relapse. ${ }^{175}$ Thus, what is in the patient's "medical interests" is to follow the standard of care. ${ }^{176}$ The standard of care does not change in the criminal setting (and should not change, given the constitutional requirement to provide medical care), and further, failing to follow the standard of care in any other setting would be medical malpractice. ${ }^{177}$

If physicians would forcibly medicate the individual in question were he in a mental hospital, or if it would be negligent not to treat a patient with an identical presentation in a non-penal setting, it follows that treatment is in the prisoner's "medical interest." Clearly, were he not slated for death, Singleton would be medicated. And even more tellingly, if the medications helped but did not quite render Singleton competent to face execution, he would be medicated. Therefore, distilling objections to the holding in Singleton down to their essence make it clear that the issue is only about the death penalty itself. ${ }^{178}$

\section{c. Medicating Singleton - a question of ethics}

Courts, as explained above, do not consider the totality of the inmate's circumstances when issuing an order for forcible psychotropic medication.

174. Alison Fife \& Jennifer Schreiber, Psychiatric Emergencies: Agitation or Aggression, UPTODATE, at $\mathrm{http}: / /$ patients.uptodate.com/topic.asp?file=psychiat/5564\&title=Psychiatric + emergency\#2 (last changed July 27, 2004).

175. Fleischhacker, supra note 75, at 84-91.

176. United States v. Weston, 134 F. Supp. 2d 115, 119 (D.C. 2001). Psychiatrists Howard Zonana and Deborah DePrato offered expert testimony on the standard of care to inform the court about appropriate treatment for a defendant who was incompetent to stand trial. The court explained that "the overwhelming evidence that antipsychotic medication is the cornerstone of treating Weston's illness." Id. at 125.

177. Id. ("Dr. Zonana stated that the standard treatment for schizophrenia is antipsychotic medication, and not to treat Weston with such medication would be medically negligent. Moreover, Drs. Zonana and DePrato testified that they were unaware of any hospital in the country that would not treat Weston with antipsychotic medication." (internal citations omitted)).

178. Judge Heaney, a vehement dissenter in Singleton, has a long history of adamant opposition to the death penalty. See Singleton v. Norris, 108 F.3d 872, 874-75 (8th Cir. 1997) (concurring, Heaney, J.).

[A]lthough I am bound to uphold the law, I write separately to add my voice to those who oppose the death penalty as violative of the United States Constitution. My thirty years' experience on this court have [sic] compelled me to conclude that the imposition of the death penalty is arbitrary and capricious. 
Critics argue that whether or not courts weigh the inmate's entire situation, physicians must consider execution as part of their decision-making process. Medical ethics demand it. As Singleton's attorney, Jeffrey Rosenzweig, said when he framed the question in Singleton's final appeal to the Supreme Court, "To what extent ... can a government take invasive, involuntary action using medical personnel who are sworn to heal, save and treat when the result of their medical application and experience is not healing, treating and saving but instead has the result of causing execution?"179 This question is curious. Medical ethics do not preclude treatment and may in fact require it.

\section{(i) Legal repercussions should not influence treatment decisions}

Physicians are ethically bound to treat a patient's illness-not what awaits him when he recovers. In sports, team physicians should weigh the player's medical situation when determining treatment options, not what will happen to the team's playoff chances if he misses the big game. Similarly, doctors should not develop treatment plans with an eye toward shielding patients from the law or influencing legal outcomes, like scheduling an elective surgery to avoid a tax court appearance, downplaying a worrisome psychiatric history so the patient can have custody of her children, or creating a diagnosis to meet worker's compensation payment standards. At best, this is an approach unfocused on medical issues; at worst, it is dishonest. Medical treatment would become a system of idiosyncratic sympathies for the most persuasive patients. That system would not comport with the ethical precept of justice, which requires that physicians offer similar treatment to patients in similar medical situations, without regard to race, class, gender or even crime, and it would smack of lying, a clear ethical violation.

Critics of this position argue that treatment decisions must incorporate the context of patients' lives and that physicians always include patients' goals in the calculus of care. Of course, it is appropriate and ethical to include patient preferences in recommendations for care. Decisions about a course of chemotherapy, for example, must consider the patient's values, balancing a chance for a longer life against the onerous side effects of treatment. Although medical decisions cannot be made in a vacuum, considering a patient's lifestyle and personal choices in the context of treatment and illness is vastly different from aiming to evade the justice system and using the physicians' unique powers to do so. Execution should not change the goals of care or the obligation to the patient more than any other impending legal consequence. ${ }^{180}$

179. Liptak, supra note 154 , at A1.

180. Furthermore, it is clearly inappropriate for physicians to express their displeasure with a social or political reality by using patients as a conduit for their opinions. If a physician abhors the fact that a beloved patient will be incarcerated for a white collar crime, he cannot 


\section{(ii) Medical ethics precludes Singleton from wallowing in psychosis}

Beneficence, another precept of medical ethics, requires that physicians act in the best interests of their patients. Singleton argued that because execution was not in his best interests overall, medication that may render him competent for execution could not be in his medical interests. It followed, he said, that because physicians who treated him would violate medical ethics, the Eighth Circuit should stay his execution. Assuming that death is not in his best interests, involuntary antipsychotic treatment does not betray beneficence. It is a balancing act. Without treatment, Singleton suffered horribly, and he actually preferred his medicated state, regardless of any side effects that may have existed. In fact, not treating Singleton would violate the ethical principle of nonmaleficence - do no harm. ${ }^{181}$ Shirking his medical care, care that he would receive in any other criminal or civil setting, is harmful. When a patient experiences extreme suffering, the unethical course may be to leave him hopelessly sick and dangerously psychotic. ${ }^{182}$

Again, it is critical to recall that no actor in the Singleton situation explicitly aimed to kill him. Notably, the Singleton court found no evidence that the physicians caring for Singleton "were in any degree motivated by the desire, purpose or intent to make Mr. Singleton competent so that he could be executed." 183 The case does not mirror Perry's medicate-to-execute scheme. Even if, as the 1982 United Nations Principles state, "it is a contravention of medical ethics for health personnel, particularly physicians, to be involved in any professional relationships with prisoners or detainees the purpose of which is not solely to evaluate, protect or improve their physical and mental

simply admit that patient to a hospital to help her duck a sentence. Physicians are also restricted from discrimination - a pro-life/anti-choice cardiologist should not turn away a patient because she had an abortion years ago. Ethics requires that physicians be, quite simply, physicians.

181. A dissenting judge in Perry agrees with this analysis and actually would have medicated Perry, absent a Harper showing. The supporting sentiment:

If, in fact, a physician is sworn to do no harm and to act only in the best medical interests of his patients, I fail to see how administering an antipsychotic drug manufactured to alleviate suffering in those for whom it is indicated, i.e., those manifesting overt psychotic symptoms, can reasonably be construed as doing harm or acting against the patient's best medical interests.

State v. Perry, 610 So.2d 746, 778 (Cole, J., dissenting).

182. Some critics argue that physicians must preserve life at all costs and that medicating an inmate who may be executed violates that requirement. Assuming that that assessment is correct, physicians do not myopically preserve life in the usual course of their practice. For example, in many cases, withholding or withdrawing life support may be the most ethical course. See, e.g., T.E. Corbett, Withholding Life-Prolonging Medical Treatment, 256 JAMA 1263 (1986).

183. Singleton v. Norris, 319 F.3d 1018, 1022 (8th Cir. 2003). 
health[,]"184 Singleton's physicians aimed to treat his psychosis and dangerousness. Were Singleton simply docile and demented, or if his symptoms were contained but he remained incompetent for execution, or if the standard of care did not support treatment, then a medication regimen devised solely to facilitate his death would, in fact, violate the ethical principles of beneficence and nonmaleficence. The distinction turns on intent.

Intent is crucial in both law and ethics. Criminal law distinguishes identical acts through the actor's intent, and mens rea is integral to proving a crime. ${ }^{185}$ As the Supreme Court explained in Vacco v. Quill, intent creates a distinction with a meaningful difference, one with strong legal and ethical roots:

The law has long used actors' intent or purpose to distinguish between two acts that may have the same result. See, e.g., United States v. Bailey, 444 U.S. 394, 403-406 (1980) ("The .. . common law of homicide often distinguishes ... between a person who knows that another person will be killed as the result of his conduct and a person who acts with the specific purpose of taking another's life"); Morissette v. United States, 342 U.S. 246, 250 (1952) (distinctions based on intent are "universal and persistent in mature systems of law"); $M$. Hale, 1 Pleas of the Crown 412 (1847) ("If A., with an intent to prevent gangrene beginning in his hand doth without any advice cut off his hand, by which he dies, he is not thereby felo de se for tho it was a voluntary act, yet it was not with an intent to kill himself'). Put differently, the law distinguishes actions taken "because of" a given end from actions taken "in spite of" their unintended but foreseen consequences. Pers. Adm'r of Massachusetts. v. Feeney, 442 U.S. 256, 279 (1979); Compassion in Dying v. Washington, 79 F.3d 790, 858 (9th Cir. 1996) (Kleinfeld, J., dissenting) ("When General Eisenhower ordered American soldiers onto the beaches of Normandy, he knew that he was sending many American soldiers to certain death .... His purpose, though, was to . . . liberate Europe from the Nazis"). ${ }^{186}$

184. Principles of Medical Ethics, G.A. Res. 37/194, U.N. GAOR, 111 th mtg., U.N. Doc. A/REX/37/194 (1982). Importantly, no court has been swayed by U.N. Principles, and at least one court has specifically rejected them. See. United States v. Weston, 134 F. Supp. 2d 115, 126 (D.C. 2001) (citing Principles of Medical Ethics, supra).

185. JOHN KAPLAN, ET AL., CRIMINAL LAW: CASES AND MATERIALS 181-286 (2000).

186. Vacco v. Quill, 521 U.S. 793, 802-803 (1997). 
In medical ethics, the intent distinction has developed its own doctrine of "double effect." 187 Behavior that might be unethical when animated by a particular underlying intent may become acceptable when the physician's aim differs. For example, a physician does not kill a patient when that patient refuses life-sustaining medical treatment. As Court explained in Vacco, "The distinction comports with fundamental legal principles of causation and intent. First, when a patient refuses life-sustaining medical treatment, he dies from an underlying fatal disease or pathology; but if a patient ingests lethal medication prescribed by a physician, he is killed by that medication." 188

The legal system already relies on physicians to differentiate their intent when treating inmates. Government physicians must separate treatment from punishment and a duty to the state from a duty to the patient. Courts may use physicians as a check on the penal system by assuming that they can focus on the disease itself. The Harper Court deferred to physicians to determine the limits of appropriate individual treatment, stating that it "will not assume that physicians will prescribe these drugs for reasons unrelated to the medical needs of the patients; indeed, the ethics of the medical profession are to the contrary." 189 The law expects physicians to act with appropriate intent.

The double effect doctrine further posits that physicians may employ a treatment intended to help the patient even if potential harm is foreseeable but unintended. In the palliative care setting, aggressive pain management may hasten death. Medical consensus supports such a course as long as pain relief remains the primary goal. As Justice Stephen Breyer explained in his Vacco concurrence, "[T] he laws of New York and of Washington do not prohibit doctors from providing patients with drugs sufficient to control pain despite the risk that those drugs themselves will kill" because the intent is to control pain, even if a foreseeable risk of that treatment is death. ${ }^{190}$ Even those who find the idea unpalatable must acknowledge that it has found a place in ethics and law, and that it is a core teaching of critical care. ${ }^{191}$ In fact, due to its

187. The birth of double effect has been attributed to Thomas Aquinas and his predecessors. See TOM L. BEAUCHAMP \& JAMES F. CHILDRESS, PRINCIPLES OF BIOMEDICAL ETHICS 160 (4th ed. 1994). It was originally employed for use in a religious context, allowing Catholics to have abortions when the intent was to save the mother's life, not to kill the fetus, and medical ethics has adopted it for its own purposes.

188. Vacco, 521 U.S. at 801 (citing People v. Kevorkian, 527 N.W. 2d 714, 728 (1994), cert. denied, 514 U.S. 1083 (1995)); Matter of Conroy, 486 A. 2d 1209, 1226 (1985) (when feeding tube is removed, death "results ... from [the patient's] underlying medical condition"); In re Colyer, 660 P. 2d 738, 743 (1983) ("Death which occurs after the removal of life sustaining systems is from natural causes"); American Medical Association, Council on Ethical and Judicial Affairs, Physician-Assisted Suicide, 10 Issues in Law \& Medicine 91, 92 (1994) ("When a life-sustaining treatment is declined, the patient dies primarily because of an underlying disease.")).

189. Washington v. Harper, 494 U.S. 210,223 n.8 (1990).

190. Vacco, 521 U.S. at 810 (Breyer, J., concurring).

191. John M. Luce \& Ann Alpers, End-of-Life Care: What Do the American Courts Say?, 29 CRITICAL CARE MED. N40 (2001). 
greater attenuation from the cause of death, double effect may be less objectionable under the facts in Singleton than in the classic circumstance of the morphine drip used to treat end-of-life pain. ${ }^{192}$ With the aggressive use of opiates, the action that may kill the patient and the action of the physician are the same. In the case of the dangerously psychotic inmate, the physician's action (treating psychosis) and the action that kills the patient (execution) are distinct by time, actor, and intervention. ${ }^{193}$

Given that reality, it is unclear why the medical community should restrict the principle of double effect and it say that it is inapplicable to treating psychotic death row inmates. If hastening death is an unintended but foreseeable consequence of aggressive pain management at the end of life, then rendering Singleton competent for execution can be characterized as an unintended but foreseeable consequence of neuroleptics that treat dangerous psychotic symptoms. ${ }^{194}$ It is not an execution preparation regime. As the New York State Task Force on Life and the Law has explained, "[M]edical treatment sometimes requires significant trade-offs, and . . . acceptance of negative consequences for legitimate medical purposes is not equivalent to causing those consequences for their own sake."195 While the Task Force was

192. Some may argue that double effect has no relevance to Singleton's situation. There is no coherent reason why the principle must be limited to one specific situation in medical ethics like physician-assisted suicide, especially when it is more difficult to distinguish intent in the end-of-life context. The principle did not originate in medical ethics, and the field cannot simply borrow it at will, picking and choosing when it is useful. Otherwise, the field faces its own double bind - that a core principle can only apply when physicians do not object to the outcome. Apparently, directly hastening death at the end-of-life through aggressive pain control is less objectionable than involuntarily medicating an inmate who may become competent for execution. If the double effect is not applicable in this case, the field should reconsider its analysis of intent in physician-assisted suicide as distinct from end-of-life care. It is true that the dying patient does not object to the physician's action and the opiates that may quicken his exit, while Singleton objects, at least when he is relatively lucid, to forced medication. But in no other setting do we allow patients to deteriorate into psychosis, object to medication, and leave them in that state. Therefore, as I explain infra, the real objection here is to execution itself.

193. Again, the causal link is tenuous even though the outcome is foreseeable. For example, assume a law student turns in a final paper late. She fails the class and cannot graduate on time. Is the professor to blame? No. The professor did not cause the student to miss graduation even though it was quite foreseeable that if he gave her a failing grade, due to the delinquency of her paper, she would not be wearing a cap and gown that spring.

194. In a letter to the Editor of the New York Times, a Boston lawyer criticized this position, calling it "the worst kind of legal thought." To him, arguing that "[e]ligibility for execution is the only unwanted consequence of the medication," as the Singleton majority did, "los[es] sight of humanity [and] devalues the entire system of law." Jonathan J. Margolis, Sanity and Execution: A Tale Worthy of Kafka, N.Y. TIMES, Feb. 14, 2003, at A30. But intentbased reasoning is applicable, and clemency is well within the rights of the governor, who is also an important actor in the legal system.

195. N.Y.STATE TASK FORCE ONLIFE AND THE LAW, N.Y. STATE DEP'T OF HEALTH, WHEN Death Is Sought: Assisted Suicide AND Euthanasia In The Medical Context: SUPPLEMENT TO REPORT (1997). 
commenting on pain relief for the dying patient, this sentiment applies with equal force in the death penalty setting. Just as the physician in the end of life context intends to ease pain rather than kill the patient (even though the medications may and often do hasten death), the physician intends to alleviate Singleton's dangerous psychotic symptoms and relieve the pain of that illness - not to kill him. The former situation is not physician-assisted suicide, and the latter is not physician-sanctioned execution. ${ }^{196}$ The distinction rests on intent.

The ethical physician will treat Singleton because medication relieves his psychosis and because that course follows the prevailing standard of care. It does not follow that this kind of treatment is equivalent to facilitating execution. But even if it did, staunch opponents of physician involvement in the execution process agree that beneficence is not lost when a dangerous or gravely ill psychotic inmate is treated, even if therapeutic success means certain death. As the American College of Physicians has said, "a delusional prisoner's self-mutilating behavior or a severely disorganized psychotic inmate's inability to eat invite the judgment that the urgency of relieving agony or forestalling an immediate threat to life outweighs the prospect of execution."197 The American Medical Association's Code of Medical Ethics concurs: "If the incompetent prisoner is undergoing extreme suffering as a result of psychosis or any other illness, medical intervention intended to mitigate the level of suffering is ethically permissible."198 In Singleton, the purpose of involuntary medication is to treat a mentally ill man. And when a prisoner, a patient, is so profoundly ill with behaviors and thoughts that make him dangerous and disabled, antipsychotics are required. ${ }^{199}$

196. The double effect principle may ring hollow for physicians who actually order forcible medication of an inmate with antipsychotics that do, in fact, render that individual competent for execution. To them, it may feel like an impossible bind. Like physicians who actively withdraw care from their patients, those involved with forcibly medicating a prisoner awaiting execution may feel that they are killing the patient. But according to intent-based logic, they are not.

197. AM. COll. OF Physicians ET Al., BREACH OF TRUST: PHYSICIAN PARTICIPATION IN EXECUTIONS INTHEUNITEDSTATES 41-42 (1994) (noting that "this exception should be sharply limited, to cases of extreme suffering or immediate danger to life.") (emphasis omitted).

198. COUNS. ONETHICAL \& JUD. AFF., AM. MEDICAL Ass'N, CODE OF MEDICALETHICS, E$2.06(2002)$.

199. But see AM. Coll. OF PHYSICIANS ET AL., supra note 197, at 42.

Treatment that restores death row inmates to competence for execution is widely believed to be unethical. However, some prison psychiatrists content that it is ethical so long as it is done for the purpose of relieving the psychiatric symptoms, rather than for the purpose of killing the inmate ... [this] distort[s] the Hippocratic commitment into an ethic of indifference to patients as persons. This indifference is underlined by the obviousness of the penal function that such treatment serves. However the treating psychiatrist understands his or her role, the ultimate, public end furthered by clinical "success" is the execution of the condemned. Psychiatric treatment that has the effect of restoring competence should thus, as a rule, be regarded as unethical. 
Faced with this conclusion, some critics may argue that even if justice, beneficence and nonmaleficence are served, autonomy, the fourth pillar of medical ethics, undermines the argument to treat. ${ }^{200}$ It does not. Important liberty interests are implicated in the right to refuse antipsychotic medications, but those rights are not limitless. Even if a surrogate decision-maker or the individual when competent refuses the medications, the court may still impose treatment. The Supreme Court in Harper specifically considered whether the incompetent prisoner was entitled to have a guardian's substituted judgment regarding the decision. As the Weston court recalled, "[i]n Harper, for instance, the inmate reportedly said he 'would rather die than take medication,' but the Court approved the treatment as in the inmate's medical interest." 201 The Harper Court found that the State's interests needed to be part of the analysis, and that the right to avoid unwanted drugs "must be defined in the context of the inmate's confinement."202 The Court also rejected arguments about consent "out of hand."203

Psychiatry has little quarrel here. ${ }^{204}$ In general, psychiatrists and courts are uninfluenced by incompetent patients' refusals, even if they refuse medications during a coherent period for future instances of psychosis and incompetence. ${ }^{205}$ Further, because forcible treatment will not necessarily create competency, we create a clumsy rule when autonomy becomes the overriding concern. What if Singleton became less psychotic and less dangerous on medications, but he was still found to be incompetent for execution? Would forced medication be acceptable? If so, then involuntarily administered psychotropics are only problematic when execution follows. A rule that neuroleptics are forbidden only when they lead to competence is overly broad. It could inhibit treatment, abandon a subset of patients, and lead to an unsafe environment for prisoners and personnel. If forced medication is only

Id. (emphasis omitted). This position carves out an exception to the intent-based analysis, used throughout medical ethics and criminal law, presumably because its authors are death penalty opponents. As I explain in Part III, there are more appropriate ways to challenge capital punishment than to mold ethical arguments to suit one's political purposes.

200. See BEAUCHAMP \& CHILDRESS, supra note 187 (discussing these core principles of medical ethics).

201. United States v. Weston, 255 F.3d 873, 878 n.4 (D.C. Cir. 2001) (internal citation omitted).

202. Washington v. Harper, 494 U.S. 210, 222 (1990).

203. Id. at 226 .

204. United States v. Weston, 134 F. Supp. $2 d 115,127$ (D.C. 2001) (holding that the government may administer antipsychotic drugs to a pretrial detainee against his will to render him competent to stand trial and holding that, in part because of psychiatry's compliance with the result, "no established ethical barriers render such treatment medically inappropriate for Weston at this time.").

205. See Jurasek v. Utah State Hosp., 158 F.3d 506, 515 (10th Cir. 1998) (finding that a statute mentioning obtaining a guardian's consent prior to administering medical treatment to an incompetent patient did not create a liberty interests beyond Harper and thus was not required). 
troubling when it makes the inmate sane enough to execute, arguments against it are a rather transparent attack on the death penalty itself. The better rule is that autonomy is not absolute. ${ }^{206}$

Finally, it is important to explain that medicating Singleton is not "participation" in an execution. ${ }^{207}$ If prescribing medically needed drugs for a death row inmate that may render him competent for execution is "participation," then really any involvement, however tangential, in the justice system could become a "but for" cause of the ultimate result. The American Medical Association's Council on Ethical and Judicial Affairs has defined participation in execution to include actions that directly cause death or help another person directly cause death. ${ }^{208}$ The action here does not fit that definition. The chain of causation is too attenuated in the Singleton situation to plausibly argue that physicians are acting as executioners or government lackeys. If a psychiatrist does not become an agent of the state when medicating a defendant for the sole purpose of making him competent for trial, why does that physician now become the executioner's handmaiden if he or she medicates an inmate for the sole purpose of treating the illness, with the acknowledged potential sideeffect that the inmate may become competent to be killed? ${ }^{209}$ It is illogical to draw a line at the physician who treats the underlying psychosis. That behavior is more tangential than the crime itself, the court's decision on

206. It may help to think of the situation as not one about mental illness, but rather, one that turns on competency. In the vast majority of cases, and certainly on death row, medical protocol is to treat the underlying cause of the delusions or delirium and restore the patient to competence. In Singleton's case, the underlying illness is schizophrenia. But incompetence can be brought on by organic problems that affect the brain, like hepatic encephalopathy, where the underlying illness could be liver failure, or a metabolic derangement, where the underlying illness could be diabetic ketoacidosis. Today, mental illness is just as treatable, in many cases, as other diseases that lead to incompetence. The acute derangement is reversible. Therefore, it merits treatment.

207. Even if it were, physician participation in executions may be ethically acceptable. See Kenneth Baum, "To Comfort Always": Physician Participation in Executions, 5 N.Y.U. J. LEGIS. \& PUB. POL'Y 47 (cogently explaining the parameters of "participation" and arguing that physician participation in executions is ethically permissible).

208. COUNS. ON ETHICAL \& JUD. AFF, supra note 198, at E-2.06.

209. But see George J. Annas, Moral Progress, Mental Retardation, and the Death Penalty, 347 NEW ENG. J. MED. 1814, 1817 (2002) ("physicians could understandably decline to participate in this way [to determine if an accused is retarded], even before trial, arguing that their participation in any phase of a proceeding that could end in the death penalty lends legitimacy to capital punishment and thus makes medicine complicit in executions."). In 1980, the American Psychiatric Association "strongly oppose[d] any participation by psychiatrists in capital punishment, that is, in activities leading directly or indirectly to the death of a condemned person as a legitimate medical procedure." AM. PSYCHIATRIC Ass'N, APA DOC. REF. No. 800002, MEdical PARTICIPATION IN CAPITAL PUNISHMENT: Position STATEMENT (1980). The APA argued that "[ $t]$ he physician's serving the state as an executioner, either directly or indirectly, is a perversion of medical ethics and of his or her role as healer and comforter." Id. This Article refutes that position-the physician is treating a patient in desperate need of care instead of letting him wallow in psychosis, just as he would treat any non-death row patient. 
appropriate punishment, the appeals courts' sanction of the death penalty, the Supreme Court's refusal to hear the case, and the Governor's refusal to issue a stay.

\section{(iii) Physicians should not use "ethics" to inject the austerity of medicine into the justice system}

Courts rely on physicians to remain detached from legal issues and adhere to their role as objective professionals focused on medical treatment. Importantly, the legal system, along with the medical community and society itself, expects doctors to treat patients only for a medical purpose, not for a punitive one. As the Court said in Harper, "we will not assume that physicians will prescribe these drugs for reasons unrelated to the medical needs of the patients[.]"210 Further, in Sell, even as the Court diluted the Harper position on dangerousness, it left medical appropriateness as a crucial part of the test for involuntary treatment. Again, the Court looked to physicians' judgment. That focus ultimately serves as a check on the government-and an important protection for the inmate-because it assumes that physicians will not advocate for a political or legal position. Rather, he or she will prescribe what is medically best for the patient. As the Supreme Court said in Harper, "an inmate's interests are adequately protected, and perhaps better served, by allowing the decision to [involuntarily] medicate [with psychotropic drugs] to be made by medical professionals rather than a judge."211 In the context of involuntary medication, the legal system defers to physicians. ${ }^{212}$ Courts rely on physicians' objective clinical judgments.

Courts seem to assume that doctors will not prescribe medications for punishment since that behavior steps outside the medical profession's role. Courts also rely on physicians to refrain from injecting their political views into medical judgments. For example, physicians in the emergency setting must triage and treat patients accused of and even arrested for heinous crimes. They must refrain from judgment and allow the justice system to take its course. Similarly, physicians should not betray their responsibility to care for the prison population by allowing their views on the death penalty to color treatment decisions. ${ }^{213}$ The legal system believes that a physician-not a

210. Washington v. Harper, 494 U.S. 210,222 n. 8 (1990).

211. Id. at 231.

212. Id. at $230 \mathrm{n} .12$. (" $[\mathrm{D}]$ eference ... is owed to medical professionals who have the fulltime responsibility of caring for mentally ill inmates ... and who possess, as courts do not, the requisite knowledge and expertise to determine whether the drugs should be used in an individual case.").

213. In Sell, the Court again reiterated the designated and limited role of physicians and why their focus must remain narrowed on treatment. The Court explained,

For one thing, the inquiry into whether medication is permissible, say, to render an individual nondangerous is usually more "objective and manageable" than the inquiry into whether medication is permissible to render a defendant competent. 
judge or a warden or an advocate - can make a dispassionate decision about medical treatment, guided by evidence, that focuses narrowly on the clinical issues involved in the case. The system relies on physicians to refrain from expanding their role into politics or policy. It needs doctors to act as doctors - not politicians, puppets of the warden, or even death penalty opponents. It depends on it.

\section{(iv) Political opinions should be expressed through the democratic process}

Aside from the Singleton setting, physicians should not deliberately act to foil the justice system in other contexts. The need to call medicating Singleton "a breach of ethics" highlights the contentiousness of the death penalty and some physicians' reluctance to be associated with it, even tangentially. However, due process was served at every step in Singleton's case, and any discomfort with the outcome becomes a problem with our legal system or the death penalty itself. The way to express disaffection for either the justice process or Singleton's punishment is not to retreat into "ethics," nor is it to include the totality of the circumstances in decisions about medical treatment. Such approaches fail on legal, ethical, and policy grounds and trump the justice system on a haphazard case-by-case basis. Not only is this an unprincipled strategy for expressing resentment towards the death penalty, it is not the appropriate use of physicians' considerable power.

We have a democratic system. It may be flawed, but it is not a totalitarian government. It is not Nazi Germany, and any comparison to physicians' roles in that regime is wrong, insulting, and dangerous. That was a system where religion, race, and sexual orientation, among other classifications, served as an excuse to violate individual rights - exactly the kind of prejudices that our Constitution aims to protect. Our courts have charged physicians with the weighty responsibility of guiding medical care for incompetent inmates. Doctors should not reconfigure and expand that role to act as the legislature, the judiciary, or the executive branch of government, creating law, interpreting law, or deciding clemency. It is not their role; it is not their place. We have political venues to challenge the death penalty, and physicians who disagree with it should use those avenues to express their displeasure. But they should not usurp that system, encroach on powers delegated to particular

The medical experts may find it easier to provide an informed opinion about whether, given the risk of side effects, particular drugs are medically appropriate and necessary to control a patient's potentially dangerous behavior (or to avoid serious harm to the patient himself) than to try to balance harms and benefits related to the more quintessentially legal questions of trial fairness and competence.

Sell v. United States, 539 U.S. 166, 213 (2003) (internal citation omitted). 
branches of government, work outside of the democratic process and, rather presumptuously, call it medical ethics.

\section{GIVEN THAT THE SINGLETON DECISION IS LEGAL AND ETHICAL, OPTIONS FOR PHYSICIANS WHO DISAGREE}

Law and ethics may allow medicating inmates like Singleton, but for many physicians, the onus of that task may be too much to bear. The profession has long wrestled with the ethics of its association with the death penalty, ${ }^{214}$ and the Singleton controversy likely reveals deep discomfort with capital punishment itself. For physicians who remain wary of treating a patient when successful therapy may mean certain death, alternatives exist.

\section{A. Opt Out}

Unless they are on an emergency team, physicians can choose their patients and procedures. A court cannot demand that a surgeon perform surgery, and it cannot order an obstetrician to terminate a pregnancy. Similarly, psychiatrists may alleviate any inner conflict by opting out of treating death row inmates. Psychiatrists who work for the state should also be allowed to opt out, as the Ethics Committee of the American Psychiatric Association has suggested. ${ }^{215}$ Regardless of cogent arguments to the contrary, some physicians may feel that the death penalty demands distinction and that forcibly medicating an inmate who faces imminent execution makes them complicit in capital punishment. Reasonable people disagree about the point where complicity begins and if participation is unethical. Physicians who remain uncomfortable with forced medication in cases like Singleton can and should decline to care for this class of patient, and they should do so consistently, without regard to a particular crime or personality. Of course, if the most conscientious physicians refuse to care for inmates sentenced to death, their dissent may leave prisoners with inferior or absent care.

\section{B. Rescind Ford}

Although Ford is grounded in the common law and the opinion of esteemed Supreme Court Justices, it is not Truth-incontrovertible and

214. AM. PSYCHIATRIC ASS'N, supra note 209 (noting that "in this century heinous crimes by physicians causing death and torture have been documented in Germany, Russia, and other countries"); see also AM. COLL. OF PHYSICIANS ET AL., supra note 197 (detailing the history of physician participation in capital punishment, including their efforts to make execution more humane and less painful).

215. Interview with Dr. Howard Zonana, Professor of Psychiatry and Clinical Professor (Adjunct) of Law, Yale University, in New Haven, Conn. (Feb. 18, 2005). 
irrefutable. It is opinion bounded by mores of a particular time and place. It may, in fact, be wrong. ${ }^{216}$

The rationales for not killing the insane may be little more than historical relic. In their book about Alvin Ford (of the Ford competence standard), Kent Miller and Michael Radelet explain why our society refrains from killing the mentally ill. ${ }^{217}$ First, from a humanitarian perspective, the mentally ill deserve special protection. They cannot care for themselves, and their illness is punishment enough. Arguably, though, the insane deserve no more protection than anyone else, and although their illness may be unpleasant or even horrifying, it is not what the state meted out. Second, killing the insane clouds the image of fair play that is crucial to our justice system. Since a mentally ill individual cannot assist in his defense, the system takes advantage of him. This argument is less convincing when, like Singleton, the defendant becomes ill after the trial. Attorneys like Jeffrey Rosenzweig serve as excellent advocates, with or without their client's input. Third, Miller and Radelet note that retribution is not achieved if the prisoner fails to appreciate his impending fate. Yet, even if he fails to understand the reason for his execution, he becomes an example for others, adding to the deterrent value of the punishment, and the family of his victim appreciates the retributive nature of his death. Further, an argument based in religious conviction says that the insane prisoner awaiting execution is unable to prepare for death. But that is a fate that befalls many non-criminals too. Sudden illness or unexpected trauma is tragic. If the issue turns on adequate time to prepare for the afterlife, it becomes just another reason to separate religion from the state. Finally, the authors note that society may be horrified by our inability to show mercy to the mentally ill, and that the prisoner's death will be overshadowed by such callousness. If that is so, it is unclear why we fail to show mercy to others with non-mental illnesses. Today, we know that mental illnesses like major depression, schizophrenia, and bipolar disorder are examples of neurochemistry gone awry. Why is this class of disease any different from other diseases where organs malfunction, like cancer, heart failure, Huntington's disease, or cirrhosis? Psychiatrists argue that depression is akin to diabetes. It is a medical disease that should be without stigma. But giving special status to mental illnesses supports that stigma. If mental illnesses are no different from any other disease, they should be treated like any other disease.

Not long ago, the California Supreme Court wrote that insanity and execution were not mutually exclusive.

216. See, e.g., Phyle v. Duffy, 208 P.2d 668, 675 (Cal. 1949) (Traynor, J., concurring) ("Taking refuge in insanity as a means of escaping execution is not a constitutional right, but a privilege that the state has conferred as an act of mercy or special dispensation.").

217. KeNT S. Miller \& Michael L. Radelet, ExeCuTing the MENTALly Ill: THE CRIMINAL JUSTICE SYSTEM AND THE CASE OF ALVIN FoRd 2 (1993). 
A study of the historical background of the cited statutes does not disclose that a convicted person, who may become insane following his conviction, has any constitutional or inherent right to have the execution of his sentence suspended by reason of such insanity. At common law the granting of an application for such suspension appears to have been discretionary with the court or the executive power in the exercise of [clemency], as a merciful dispensation, an act of grace. In such cases there was no absolute right to a hearing and the ruling of the trial court was not subject to review by appeal. $^{218}$

Professor Henry Weihofen has argued that it may be more humane to execute prisoners while they are insane, to spare them the terror of waiting for death. ${ }^{219}$ As he put it, "[t]he real issue is whether it is less humane to execute a guilty criminal while he is insane than it is to postpone the execution until we make sure that he understands what we mean to do to him - and then kill him." ${ }^{220}$ California's Justice Traynor asked a compelling question:

Is it not an inverted humanitarianism that deplores as barbarous the capital punishment of those who have become insane after trial and conviction, but accepts the capital punishment of sane men, a curious reasoning that would free a man from capital punishment only if he is not in full possession of his senses? $?^{221}$

But for stare decisis, there is little reason why perspectives like these cannot shape the rule of the day. If Ford vanished, physicians' conflict in cases like Singleton would also disappear. Still, the normative value of Ford and its deference to a core standard of human decency remains.

\section{Clarify and Heighten the Competence Standard}

Singleton's state of mind calls into question the usefulness of the Ford standard. The bar may be too low. As University of Florida Levin College of Law Professor Christopher Slobogin explained on ABC's Nightline, "[s]ome people can repeat back to one in a rote, parrot-like manner[,] ['Y]es, I understand the death penalty means I will die and yes, I understand that's because I killed someone.['] But," he continued, "unless the person really has a clear

218. People v. Riley, 235 P.2d 381, 384 (Cal. 1951).

219. Henry Weihofen, $A$ Question of Justice: Trial or Execution of an Insane Defendant, 37 A.B.A. J. 651 (1951).

220. Id. at 652 .

221. Phyle, 208 P.2d at 676-77 (Traynor, J., concurring). 
appreciation of why he or she is being executed, then we don't [execute him]. One court put it this way. Unless the person quails at the imposition of the death penalty we shouldn't impose it on them."222

States suspend executions until the inmate regains competence, ${ }^{223}$ but the standard could be changed so that inmates with mental illnesses would be immune from execution. Inmates, like Singleton, who understand the point and nature of execution may suffer from chronic illness: "The voices inside Charles Singleton's head vary, in volume and number, regardless of whether he has taken medication for his schizophrenia. Inside his Arkansas cell, he says he can often hear voices that speak of killing him."224 If society is uncomfortable with killing mentally ill inmates, then the competency standard as the threshold for execution may need to be altered.

Further, competency determinations may be overly subjective. Professor Bruce Winick argues that "the criteria used to define [mental illness] are ... imprecise and their application inevitably involves value judgments, often beyond the professional competence of clinicians." ${ }^{225}$ Although attempts have been made to make the evaluation objective, it may not be impartial enough. ${ }^{226}$ Even so, the treatable nature of the manifestations of some mental illnesses means that only the most refractory patients will fall outside of competency boundaries. In that case, we may need to become comfortable with executing inmates who have underlying mental illnesses, just as they may have other underlying chronic diseases.

\section{Commute Sentences to Abolish the Death Penalty for the Insane}

Capital punishment still enjoys wide public support among Americans. A Gallup Poll conduct in October 2003 found that almost two-thirds of Americans surveyed supported the death penalty. ${ }^{227}$ But when asked about executing mentally ill inmates, opinions changed. According to a poll of 1,012 Americans taken in May 2002, "75 percent of those surveyed opposed

222. Nightline: Executing the Mentally Ill (ABC television broadcast, May 19, 1998). Professor Slobogin is the Stephen C. O'Connell Chair, Professor of Law, Affiliate Professor of Psychiatry, and Associate Director, Center on Children and the Law, available at http://www.law.ufl.edu/faculty/slobogin/index.shtml (last visited Apr. 17, 2005) (on file with the Indiana Health Law Review).

223. See, e.g., ALA. CODE § 15-16-23 (2005).

224. Drew, supra note 55.

225. WINICK, supra note 79, at 159.

226. Arrigo \& Williams, supra note 135, at $374 \mathrm{n} .28$ (1999) (listing articles on determining competency); Charles Patrick Ewing, Diagnosing and Treating "Insanity" on Death Row: Legal and Ethical Perspectives, 5 BEHAV. SCI. \& L. 175, 175-85 (1987); Patricia A. Zapf et al., Assessment of Competency for Execution: Professional Guidelines and an Evaluation Checklist, 21 BEHAV. SCI. \& L. 103, 103-20 (2003) (discussing professionalism issues in psychiatry, creating a checklist towards an "objective assessment of competency for execution").

227. Drew, supra note 55. 
executing mentally ill inmates, while 19 percent supported it." ${ }^{228}$ This ambivalence may indicate Americans' willingness to move the mentally ill off of death row.

Courts and legislatures could capitalize on this support to create a bright line rule that commutes death sentences for inmates suffering from mental illnesses. An unequivocal directive protects due process because it puts everyone on notice about individuals who cannot face execution. It may also be a step toward fairness. Perhaps individualized decisions are too whimsical, too uncertain, too dependent on mood and mercy. Moreover, it would not be a unique declaration. Particular classes of individuals, like the mentally retarded, are immune from capital punishment. ${ }^{229}$ Similarly, we could extend that protection to another group. Such a law would also eliminate the psychiatrist's dilemma, as medication and execution competence would be untangled.

Perhaps such a rule would make our society more humane. As Singleton's attorney has argued, "[I]t offends social standards of decency to execute someone whose competency has been involuntarily obtained."230 To be sure, a ban on executing prisoners with mental illness would fall in line with international standards. As Amnesty International reported, "In 1997, the UN Special Rapporteur on Extrajudicial, Summary or Arbitrary Executions stated that governments that continue to use the death penalty 'with respect to minors and the mentally ill are particularly called upon to bring their domestic legislation into conformity with international legal standards." ${ }^{231}$ In April 2000, the UN Commission on Human Rights urged all states that maintain the death penalty "not to impose it on a person suffering from any form of mental disorder; not to execute any such person."232 According to Amnesty International, imposing capital punishment on individuals with a mental illness "is clearly prohibited by international law. Virtually every country in the world prohibits the execution of people with mental illness."233

Yet, the rule is not impervious to criticism. It remains unclear why criminals with mental illnesses deserve special treatment if he can understand the nature of and reason for his punishment. The rule rewards neurobiology gone awry. In a very real sense, the rule is unfair to those who are not insane as well as those who suffer from a general medical illness. Also, prisoners

228. Id.

229. Atkins v. Virginia, 536 U.S. 304, 321 (2002) (holding that death is an unconstitutionally cruel and unusual punishment for mentally retarded criminals).

230. Rachel O'Neal, Sanity Dose Approved For Inmate Court Rules State Can Medicate Killer To Make Him Fit For Execution, ARK. DEMOCRAT-GAZETTE, June 18, 1999, at A1.

231. Amnesty International USA, Death Penalty Facts: The Death Penalty Kills the Mentally Ill, at http://www.amnestyusa.org/abolish/mental_illness.html (last visited Apr. 17, 2005) (on file with the Indiana Health Law Review).

232. Id.

233. Id. 
could attempt to feign mental illness, difficult as that may be, to gain the execution exemption. ${ }^{234}$

\section{E. Physicians Who Oppose the Involuntary Medication of Inmates Like Singleton Should Lobby to Eradicate the Death Penalty}

Attempts to mold principles of medical ethics into a coherent, convincing argument against medicating Singleton seem like anti-death penalty sentiment and attempts to hide behind the cloak of "medical ethics" to usurp the legal process surrounding execution. Even the American Medical Association's Code of Ethics concludes that "[i]f the incompetent prisoner is undergoing extreme suffering as a result of psychosis or any other illness, medical intervention intended to mitigate the level of suffering is ethically permissible." ${ }^{235}$ The arguments underlying physicians' position against medicating prisoners who truly need psychiatric help mask a gut reaction that execution itself, or executing the mentally ill, just feels wrong. At its core, the debate reveals a deep discomfort with the death penalty. If it is barbaric to execute the insane, unethical to forcibly treat inmates who become competent for execution when medicated, unsavory to let people wallow in psychosis to avoid execution, and unprincipled to commute the sentences of those who have the mixed fortune of becoming psychotic, the only consistently fair solution may be to eliminate the death penalty altogether. Physicians, including psychiatrists who side with Judge Heaney in the Eighth Circuit's decision in Singleton $v$. Norris should take a clear and consistent approach and ask legislatures and courts to abolish capital punishment.

Psychiatrists would find easy allies. The death penalty itself remains controversial. ${ }^{236}$ Among the more august and fierce opponents of the death penalty, Justice William J. Brennan, Jr., called capital punishment "uniquely degrading to human dignity."237 Benjamin N. Cardozo School of Law

234. Although mental illness may be difficult to simulate, literary and historic examples illustrate its appeal. The Bible's King David, Shakespeare's Hamlet, and Ovid's Ulysses all feigned madness to avoid one fate or another, as did Russian revolutionary Kamo and Arabic scientist and mathematician Abu Ali ibn Al-Haytham. See Margaret MacMillan, PARIS 1919: Six MONTHS ThAT CHANGED THE WORLD 209 (2001); Museum Victoria Australia, Scientists \& Discovery: Abu Ali ibn Al-Haytham, at http://www.museum.vic.gov.au/scidiscovery/ scientists/al_haytham.asp (last visited Apr. 17, 2005) (on file with the Indiana Health Law Review).

235. COUNS. ON ETHICAL \& JUD. AFF, supra note 198, at E-2.06.

236. Stuart Taylor, The Death Penalty Debate Intensifies, NEWSWEEK WEB EXCLUSIVE, June 11, 2001 (discussing shifts in public opinion and presidential rationales for the death penalty); see also BEYOND REPAIR?: AMERICA's DEATH PENALTY 2 (Stephen P. Garvey ed., 2003) (discussing trends in support for the death penalty); FRANK G. CARRINGTON, NEITHER CRUEL NOR UNUSUAL (1978) (defending the death penalty and its necessity in society).

237. Glass v. Louisiana, 471 U.S. 1080 (1985) (Brennan, J., with whom Marshall, J. joins, dissenting from denial of certiorari) (citing Furman v. Georgia, 408 U.S. 238, 287-91 (1972)) (internal quotations omitted). 
Professor Barry Scheck continues to uncover evidence of erroneous convictions of death row inmates through his Innocence Project. ${ }^{238}$ In 2000, Illinois governor George Ryan declared a moratorium on executions in his state after DNA evidence exonerated a number of inmates. ${ }^{239}$ Other professional associations have taken such a stance. The American Bar Association has concluded that "the death penalty is administered in an unfair and arbitrary manner" and the group recommended a moratorium on executions until the system is changed. ${ }^{240}$ The American Psychiatric Association also endorses a moratorium "until jurisdictions seeking to reform the death penalty implement policies and procedures to assure that capital punishment, if used at all, is administered fairly and impartially in accord with the basic requirements of due process." ${ }^{241}$ But the Association stopped short of adding teeth to its decree: "The statement, prepared by the Council on Psychiatry and the Law, was approved as amended, with the proviso that the language is intended neither as an endorsement nor a statement of disapproval of the death penalty." 42 Similarly, "[t]he AMA has a "long-standing tradition to remain neutral on matters that are considered to be non-medical."'243 These groups should take a stand on the death penalty. All physicians should participate in the ongoing debate about the appropriateness of capital punishment. ${ }^{244}$

What makes the most sense, though, is to end the system that endorses accidents of biology and protects certain classes from the death penalty, and eliminate the punishment itself. Physicians who oppose treating Singleton should lobby against the death penalty. While the Supreme Court holds that capital punishment is constitutional, that position may change. Because the Court looks to prevailing social norms and public values when considering the

238. Innocence Project, at http://www.innocenceproject.org (last visited Apr. 17, 2005)(on file with the Indiana Health Law Review).

239. Franco Ordonez, Death Row Appeal Challenges Rule Limiting Filings, Boston GLOBE, Feb. 24, 2004, at A1 (mentioning the Illinois moratorium on executions). Of course, governors, like the American population, take varying positions on the issue. Minnesota Governor Tim Pawlenty wants to resurrect the death penalty in his state-that state's legislature repealed the penalty in 1911 - but Pawlenty wants to implement safeguards like a requirement for DNA evidence, a ban on executing minors and the mentally disabled, and a requirement that death may not be imposed if the prosecution based its case on one eyewitness's testimony, an informant's testimony, or uncorroborated accomplice testimony. National Briefing, Midwest - Minnesota: Return of Death Penalty, N.Y. TIMES, Jan. 28, 2004, at A19.

240. AM. PSYCHIATRIC Ass'N., APA DOC. REF. NO. 200006, MORATORIUM ON CAPITAL PUNISHMENT IN THE U.S.: POSITION STATEMENT (2000), available at http://www.psych.org/edu/other_res/lib_archives/archives/200006.pdf.

241. Id.

242. Id.

243. Jim Ritter, AMA Opposes Scouts' Gay Ban, ChICAGo SUN-TimES, June 21, 2001, at 14.

244. See Annas, supra note 209, at 1817 (discussing physicians' "special ethical responsibility to participate actively in the ongoing debate over capital punishment"). 
scope of the Eighth Amendment, ${ }^{245}$ professional opinions that critique capital punishment may impact the judiciary. They could also (perhaps more appropriately) influence law-making in the legislature. A consensus that the death penalty is cruel and unusual could eliminate capital punishment altogetherand the dilemma for physicians would disappear. Physicians could then medicate individuals who need psychiatric or medical care while they are incompetent without worrying about capital punishment. The white coat would remain pristine. Anything less is tortured logic masquerading as medical ethics.

\section{EPILOGUE}

At the beginning of its October 2003 Term, the United States Supreme Court denied Singleton's final writ of certiorari ${ }^{246}$ It was the final obstacle between Singleton and the executioner's needle. The quest for exoneration, or at least a permanent stay of execution, was over. As the hour of execution approached, Singleton's attorney asked Arkansas Governor Mike Huckabee for clemency, even though his client "had begged him not to do anything to stop the execution." $" 247$ Huckabee denied that request. ${ }^{248}$

245. See Atkins v. Virginia, 536 U.S. 304, 311 (2002) (remarking that constitutionally based judgments about excessive punishment are to be made on the basis of opinions that "currently prevail" and that the Court looks to Americans' values and national consensus regarding death penalty issues); Ford v. Wainwright, 477 U.S. 399, 406 (1986) ("[T]his Court takes into account objective evidence of contemporary values before determining whether a particular punishment comports with the fundamental human dignity that the Amendment protects."); Trop v. Dulles, 356 U.S. 86, 100 (1958) (As Chief Justice Warren explained, "The basic concept underlying the Eighth Amendment is nothing less than the dignity of man .... The Amendment must draw its meaning from the evolving standards of decency that mark the progress of a maturing society."). But see Atkins, 536 U.S. at 322 (Rehnquist, C.J., dissenting) (declaring his unhappiness with an approach that uses "foreign laws, the views of professional and religious organizations, and opinion polls in reaching its conclusion" rather than legislatures and juries).

246. Singleton v. Norris, 540 U.S. 832 (2003).

247. Traci Shurley, Singleton Dies, ARK. DemOCRAT-GAZETTE, Jan. 7, 2004, at 11. It is ironic that Rosenzweig, so opposed to involuntary medication, filed an involuntary appeal. Of course, clemency would mean life for Singleton, but the involuntariness of the appeal is interesting, nonetheless.

248. Id. Shurley reported that the governor's decision "fell in line with a recommendation by the state's Post Prison Transfer Board" and reporting that "representatives from the Arkansas American Civil Liberties Union and the state office of the National Alliance for the Mentally Ill held a news conference in the state Capitol" to pressure the governor's clemency decision. Following that event, members of the Singleton family tried to meet with the governor to discuss the case. Singleton's younger sister, Denise Hipps, told Shurley, "'Only God or the governor can stop this. . . We're already talking to God, the next step is to talk to [the governor]." Previously, a staff member from the governor's office had spoken with the family, and the governor turned them away - the usual practice regarding meetings with relatives of applicants for clemency. The family had argued that Singleton was "incompetent" and therefore should not be executed. 
Unquestionably, Singleton remained mentally ill as his execution approached. In an interview with CNN the week before his death, Singleton spoke about the voices that haunted him. ${ }^{249}$ He explained, "They talk about, for example, '[1]et's hold him and see when his father come. We'll have him and his father.' They talk about ruling the world and finding a way to kill me."250 Even his final statement seemed confused or perhaps pious: "The blind think I'm playing a game. They deny me, refusing me existence. But everybody takes the place of another. As it is written, I will come forth as you go." 251 As CNN reporter Brian Cabell explained, "[I]s this man sane as he approaches his execution? I can tell you, we met with him on death row just week ago, as a matter of fact. He is not like you or me. He rants. He raves. He rambles. He occasionally loses his train of thought."252 But Singleton's ongoing battle with schizophrenia did not preclude him from competence under Ford. ${ }^{253}$ As Cabell reported:

But on the narrow definition of sanity that applies here, does he understand what is going to happen to him, does he understand why, the answer would certainly be yes. He understands that he is going to be executed. He understands it's because he killed a woman some 24 years ago. Even his attorney would agree to that. ${ }^{254}$

Indeed, Rosenzweig said that Singleton "was generally in the past several months saner, more stable and more rational than he had been in a long time, as long as I've known him.".255 Because he understood that he killed Mary Lou York and that his punishment was death, his execution would be carried out.

So the Singleton saga reached its inevitable end with fried eggplant, fried green tomatoes, fried sweet potatoes, two double cheese veggie burgers with barbecue baked beans, potato salad and two Cokes. ${ }^{256}$ It was the first last meal of 2004 for Arkansas, ${ }^{257}$ and it was a dinner that the State had been

249. Cabell, supra note 170.

250. Id.

251. Shurley, supra note 247 , at 11 .

252. Paula Zahn Now: Is America Safer?; Princess Diana's Conspiracy Theory (CNN television broadcast, Jan. 6, 2004).

253. Ford v. Wainwright, 477 U.S. 399 (1986).

254. Paula Zahn Now, supra note 252.

255. Shurley, supra note 247 , at 11 .

256. Id. at 11 (detailing Singleton's last meal).

257. See Death Penalty Information Center, Executions in the United States in 2004, at $\mathrm{http}: / / \mathrm{www}$.deathpenaltyinfo.org/article.php?scid=8\&did=839 (last visited Apr. 17, 2005) (on file with Indiana Health Law Review). 
waiting to serve for 21 years, six months and two days. ${ }^{258}$ It had taken decades, but due process was met, the sentence was constitutional, and the journey would end on January 6, 2004, sometime after dessert-glazed doughnuts and two vanilla milkshakes. ${ }^{259}$ At 8:06 p.m. that evening, Arkansas finally executed Charles Laverne Singleton, a man who had lived on that state's death row longer than anyone else in its history, by lethal injection. ${ }^{260}$ Singleton came full circle, ending up exactly where he started-in the execution chamber. Fourteen people watched him die, ${ }^{261}$ including his attorney Rosenzweig and prosecutor John Gibson, and, according to those witnesses, Singleton went quietly to his death. ${ }^{262}$

One's perspective necessarily colors the meaning of Singleton's execution. Singleton was said to have welcomed death because he was "tired of this world"263 and, according to Rosenzweig, "tired of living with mental illness." "264 That sentiment marked a change for Singleton. Just a few years ago he told an interviewer, "I don't want to die. I want to live. But I know there's a possibility that I will die."265 Rosenzweig, who had represented Singleton in all of his appeals, "described himself as "frustrated, disappointed, saddened' by the execution," 266 calling it "a shameful mark on the state of Arkansas, because we're talking about the execution of someone who was clearly mentally ill."267 Perhaps the York family members found whatever

258. Singleton v. Lockhart, 653 F. Supp. 1114, 1115 (E.D. Ark. 1986) (noting Singleton's original execution date).

259. Shurley, supra note 247 , at 11 .

260. Id. ("Charles Singleton, the state's longest-serving death-row inmate, was executed as planned Tuesday. He was pronounced dead at 8:06 p.m.").

261. 14 Observe State's Execution of Singleton, ARK. DEMOCRAT-GAZETTE, Jan. 7, 2004, at 15 . The names and affiliations of the witnesses:

Drew Baker, Arkansas Department of Correction board member; Brett Morgan of Little Rock; Gary Canda of England; Eric Walker of the state attorney general's office; John F. Gibson Jr. of Monticello, who prosecuted Singleton; Thomas Smith of England; Harold Pointer of Pine Bluff; Griffin Smith, executive editor, Arkansas Democrat-Gazette; state Sen. Jimmy Jeffress, D-Crossett; Jeff Rosenzweig, Singleton's attorney; and Gaylon White, Singleton's spiritual adviser. Members of Arkansas media allowed to attend for the purpose of news coverage were: David Hammer, The Associated Press; Jason Friedman, KARK television station, Little Rock; and Warren Watkins, Ashley County LedgerMena Star.

Id.

262. Live From . . : Execution Debate Rages On, (CNN television broadcast, Jan. 7, 2004).

263. Paula Zahn Now: Interview With Senator John Kerry and Teresa Heinz Kerry; Pete Rose Admits Betting on Baseball (CNN television broadcast, Jan. 5, 2004).

264. Drew, supra note 55.

265. Dateline NBC: Crazy Like a Fox?, supra note 4.

266. Cabell, supra note 170.

267. Live From. ... Execution Debate Rages On (CNN television broadcast, Jan. 7, 2004).

Other mentally ill inmates have faced execution. According to Amnesty International:

[A]s recently as January 21,2000 , Larry Keith Robison, diagnosed with 
peace they were looking for as they watched the execution over closed-circuit television. $^{268}$ As Mary Lou York's son Charles predicted about the eventual execution, "[i]t would bring closure for my brothers and sisters and I. It destroyed our family bad enough as it is."269 For the medical community, the legal system, and the public, the lesson of the case remains in flux. ${ }^{270}$

Charles Singleton died at age 44 . His death was shocking and unsurprising. After all those years, Singleton seemed invincible, out-foxing his opponents at every turn. He could always find another issue to parry and riposte, just one more time. In the context of appeal after appeal after appeal, he had seemingly become the protagonist. Singleton versus the State. And in stories of epic legal battles, doesn't the protagonist always win?

Though the Singleton case has ended, its legacy is a paradox. I believe in the arguments set forth here. I believe that psychiatrists have an ethical duty to medicate prisoners in clinical situations like that of Charles Singleton. I believe that psychotic inmates deserve treatment, the kind of care that they would get in the outside world, and that psychiatrists should not deny that treatment because the inmate may become competent for execution. But that does not mean that I would have cheered at Singleton's execution, nor would

schizophrenia, was executed by the state of Texas. On June 22, 2000, Thomas Provenzano, who suffered from severe delusional episodes and believed he was Jesus Christ, was executed by the state of Florida. On August 16, 2000, John Satterwhite, who suffered from both mental illness and mental retardation, was executed by the state of Texas. Others with mental illness who have been executed in the U.S. in violation of international law include: Pernell Ford (Alabama); Bert Hunter (Missouri); and Juan Soria (Texas).

Amnesty International USA, Death Penalty Facts: The Death Penalty Kills the Mentally Ill, at http://www.amnestyusa.org/abolish/mental_illness.html (last visited Apr. 17, 2005)(on file with the Indiana Health Law Review). Presumably, these inmates met the Ford standard for competence.

268. 14 Observe State's Execution of Singleton, supra note 261, at 15 . York's family members who saw the execution via closed-circuit television were: Charles York, victim's son; Mildred Arrington, victim's daughter; Jerry Pryor, victim's nephew; Sherry Arrington, victim's granddaughter; and Dell Arrington, victim's granddaughter.

269. Dateline NBC: Crazy Like a Fox?, supra note 4.

270. Singleton will not be the last case to present the issue of involuntary medication with the byproduct of competency for execution. See ABC Online, Foreign Correspondent: U.S.A.-Death Row Medication, at http://www.abc.net.au/foreign/stories/s894253.htm (last visited Apr. 17, 2005) (on file with the Indiana Health Law Review) (providing a synopsis of BBC: U.S.A.-Death Row Medication (BBC television broadcast Aug.7, 2003)). Tim Samuels reported that:

Gregory Thompson has been on death row at Nashville's Riverbend Maximum Security Institution for 17 years, convicted for a brutal murder. He tells Samuels that he has written all the popular songs on the radio, and also that he is planning to buy homes in Hawaii and New York. He also claims to have made millions from the stock market. Thompson's defence lawyer is convinced that he is insane, an assessment supported by an independent psychologist, who tells Samuels that when not medicated, Thompson refuses to clean himself or eat, and believes he is living on a slave ship. 
I dance on his grave. The reasons that death penalty opponents cite are convincing-killing Singleton will not bring back his victim; execution may not deter future killers; a life sentence is cheaper than the requisite appeals by orders of magnitude; given a different lawyer/skin color/jurisdiction, the outcome would have been different; and so on. To even the most callous observer, the inconsistencies in the punishment and the innocents exonerated from death rows around the country makes capital punishment seem "irrational, arbitrary, and unfair."271 Still, I would have treated Charles Singleton. And yet I remain troubled by the pointlessness of his crime and uneasy with the manner of his death. 